\title{
Synthesis and Immunoadjuvant Activity of the Conjugates of 1-Thio- $N$-acetyl-muramoyl Dipeptide with Lipid A Subunit Analogs ${ }^{\dagger}$
}

\author{
Yuji Ogawa, Masayuki Kitagawa, Yushun Fujishima, \\ Makoto Kiso, Akira Hasegawa, Hideharu Ishida* \\ and Ichiro AzUMA* \\ Department of Applied Bioorganic Chemistry, Gifu University, \\ Gifu 501-11, Japan \\ *Institute of Immunological Science, Hokkaido University, \\ Sapporo 060, Japan \\ Received October 24, 1988
}

\begin{abstract}
A variety of immunomodulators were synthesized by combining biologically active derivatives of 1-thio-muramoyl dipeptide with 4-O-phosphono-D-glucosamine derivatives related to bacterial lipid $A$, and using the (succinoylamino)undecanoyl group as a spacer. Their immunoadjuvant activities in guinea-pigs were examined.
\end{abstract}

In the course of a synthetic approach ${ }^{1)}$ to design a new type of immunomodulator by coupling the biologically active derivative of $N$-acetyl-muramoyl dipeptide $(\mathrm{MDP})^{2)}$ with derivatives related to the nonreducing subunit of lipid $\mathrm{A},{ }^{3)}$ it was found that the conjugate of $\mathrm{N}$-[2-O-(2-acetamido-1,5-anhydro-2,3dideoxy-D-glucitol-3-yl)-D-lactoyl]-L-alanyl-Disoglutamine methyl ester (1-deoxy-MDP methyl ester $)^{4)}$ with 2-deoxy-4-O-phosphono3-O-tetradecanoyl-2-(3-tetradecanoyloxytetradecanamido)-D-glucopyranose (GLA-27) ${ }^{5}$ through acylamido spacer-arms showed strong immunoadjuvant activity. ${ }^{6)}$ Especially, the compound carrying the (succinoylamino)undecanoyl group as a spacer expressed the highest degree of immunoadjuvant activity, and more strongly enhanced the colony stimulation factor (CSF)-inductive activity than that of GLA-27 alone. ${ }^{1 \mathrm{~b})}$

Recent studies ${ }^{7)}$ on MDP analogs showed that potent antitumor and anti-infection activities were effectively expressed by the introduction of lipophilicity at C-6 or at both C-1 and C- 6 of the sugar skeleton in 1-thio-MDP.
These compounds did not exhibit such side effects as pyrogenic activity and necrosisinducing activity, ${ }^{8)}$ in contrast to MDP.

Among the lipid A-subunit analogs $s^{9)}$ synthesized with special reference to fatty acid substituents, GLA-60 $0^{9 a}$ carrying 2-N-linked (3R)-3-hydroxytetradecanoyl and 3-O-linked (3R)-3-tetradecanoyloxytetradecanoyl groups showed the strongest $B$ cell activation and adjuvant activities. ${ }^{10)}$ In view of these facts, we synthesized a series of novel conjugates (43 45, 52 54, 57 and $64 \sim 66$ ) of 1-thio-MDP with lipid A-subunit analogs, expecting a new type of immunomodulator, and now describe their syntheses and biological activities.

\section{Results and Discussion}

The 1-thio-DMP methyl ester derivatives ${ }^{7)}$ $(\mathbf{3} \sim 5)$ were coupled with $N$-protected aminoundecanoic acid (2), in the presence of dicyclohexylcarbodiimide (DCC) and 4-dimethylaminopyridine (DMAP), to give 6-O-[11-(tertbutoxycarbonylamino) undecanoyl]-1-thioMDP methyl ester derivatives $(\mathbf{6} \sim \mathbf{8})$ in good

$\dagger$ Studies on Immunoadjuvant Active Compounds. Part XXXVII. For Part XXXVI, see ref. Ib. 
$\mathrm{RNH}\left(\mathrm{CH}_{2}\right\}_{10} \mathrm{COOH}$

\begin{tabular}{cc}
$\frac{\mathrm{R}}{1}$ & $\mathrm{H}$ \\
\hline 2 & Boc
\end{tabular}

Boc: tert-Buocio)

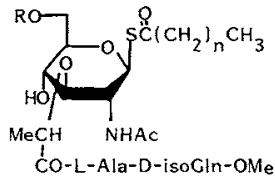

H

$\mathrm{H}$

$\mathrm{H}$

BocNH $\left(\mathrm{CH}_{2}\right)_{10} \mathrm{ClO}$

$\mathrm{BoCNH}\left(\mathrm{CH}_{2}\right)_{10} \mathrm{C}(\mathrm{O})$

$\left.\mathrm{BocNH}\left(\mathrm{CH}_{2}\right)_{10} \mathrm{ClO}\right)$

TFA. N H ${ }_{2}\left(\mathrm{CH}_{2}\right){ }_{10} \mathrm{ClO}$

TFA. N $\mathrm{H}_{2}\left(\mathrm{CH}_{2}\right) \mathrm{ClO}$

$\mathrm{TFA} \cdot \mathrm{N} \mathrm{H}_{2}\left(\mathrm{CH}_{2}\right)_{10} \mathrm{C}(\mathrm{O})$
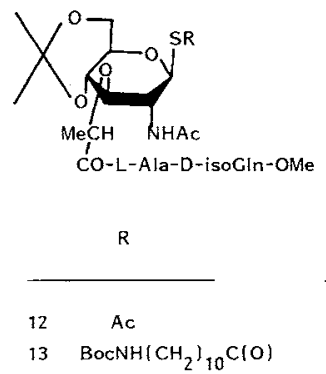

$\left.13 \mathrm{BocNH}\left(\mathrm{CH}_{2}\right)_{10} \mathrm{ClO}\right)$

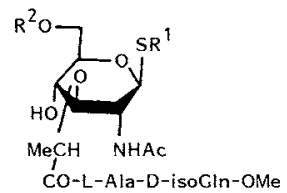

\begin{tabular}{lll} 
& $\mathrm{R}^{1}$ & $\mathrm{R}^{2}$ \\
\hline 14 & BocNH $\left(\mathrm{CH}_{2}\right){ }_{10} \mathrm{C}(\mathrm{O})$ & $\mathrm{H}$ \\
15 & BocNH $\left(\mathrm{CH}_{2}\right){ }_{10} \mathrm{C}(\mathrm{O})$ & $\left.\mathrm{CH}_{3}\left(\mathrm{CH}_{2}\right)_{8} \mathrm{ClO}\right)$ \\
16 & BocNH $\left(\mathrm{CH}_{2}\right){ }_{10} \mathrm{C}(\mathrm{O})$ & $\mathrm{CH}_{3}\left(\mathrm{CH}_{2}\right)_{16} \mathrm{C}(\mathrm{O})$ \\
17 & TFA.N $\left.\mathrm{H}_{2}\left(\mathrm{CH}_{2}\right)_{10} \mathrm{ClO}\right)$ & $\mathrm{H}$
\end{tabular}

18 TFA $-\mathrm{N} \mathrm{H}_{2}\left(\mathrm{CH}_{2}\right)_{10} \mathrm{C}(\mathrm{O})$

19

$$
\left.\mathrm{CH}_{3}\left(\mathrm{CH}_{2}\right)_{8} \mathrm{ClO}\right)
$$$$
\mathrm{CH}_{3}\left(\mathrm{CH}_{2}\right){ }_{16} \mathrm{C}(\mathrm{O})
$$

TFA: $\quad \mathrm{F}_{3} \mathrm{CC}(\mathrm{O}) \mathrm{OH}$
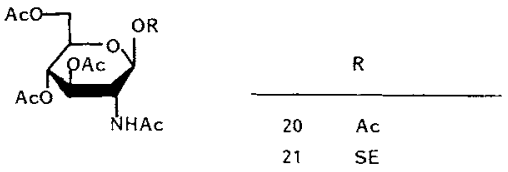

$\mathrm{SE}: \mathrm{Me}_{3} \mathrm{SiCH}_{2} \mathrm{CH}_{2}$
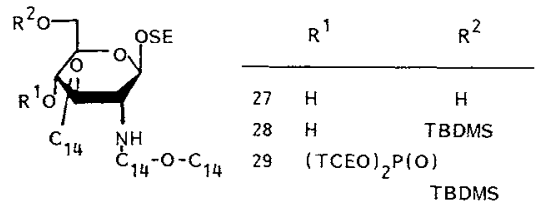

30 (TCEO) ${ }_{2} \mathrm{P}(\mathrm{O}) \mathrm{H}$

31 (TCEO) ${ }_{2} \mathrm{P}(\mathrm{O})$

$$
\left.\mathrm{HOC}(\mathrm{O})\left(\mathrm{CH}_{2}\right)_{2} \mathrm{ClO}\right)
$$

$\left.\mathrm{C}_{14}: \mathrm{CH}_{3}\left(\mathrm{CH}_{2}\right\}_{12} \mathrm{ClO}\right)$

$\mathrm{C}_{14}$-OH: $\left.\mathrm{CH}_{3}\left(\mathrm{CH}_{2}\right)_{10} \stackrel{\mathrm{O}}{\mathrm{C}} \mathrm{HCH}_{2} \mathrm{ClO}\right)$

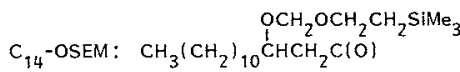

$$
\begin{aligned}
& \mathrm{C}_{14}-\mathrm{O}-\mathrm{C}_{14}: \mathrm{CH}_{3}\left(\mathrm{CH}_{2}\right)_{10} \stackrel{\mathrm{O}-\mathrm{C}_{14}}{\left.\mathrm{CHCH}_{2} \mathrm{ClO}\right)}
\end{aligned}
$$
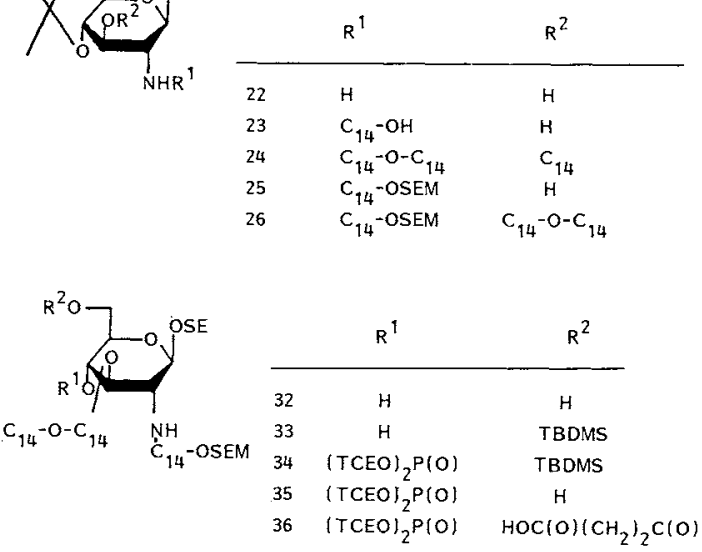

TBDMS : tert-BuMe, $\mathrm{Si}$

TCE : $\mathrm{Cl}_{3} \mathrm{CCH}_{2}$ yields. For the synthesis of the 1-S-[11-(tertbutoxycarbonylamino)undecanoyl] derivatives $(14 \sim 16)$, the 1-S-acetyl group in 12 was selectively solvolyzed with sodium methoxide at $-25^{\circ} \mathrm{C}$. The reaction mixture was deionized with cation-exchange resin, and then coupled with 2 in the presence of DCC to afford $\mathbf{1 3}$ in a $68 \%$ yield. The isopropylidene group of 13 was hydrolyzed, and the resulting 14 was esterified at O-6 to give 15 and 16 in $86 \%$ and $65 \%$ 

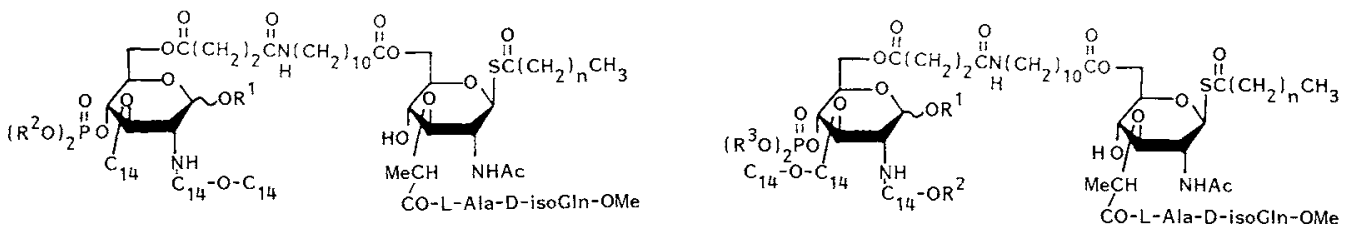

\begin{tabular}{llll} 
& $R^{1}$ & $R^{2}$ & $n$ \\
\hline 37 & SE (B) & TCE & 0 (SAC) \\
38 & SE (B) & TCE & 8 \\
39 & SE (B) & TCE & 16 \\
40 & $H$ & TCE & 0 (SAC) \\
41 & $H$ & TCE & 8 \\
42 & $H$ & TCE & 16 \\
43 & $H$ & $H$ & 0 (SAC) \\
44 & $H$ & $H$ & 8 \\
45 & $H$ & $H$ & 16
\end{tabular}

\begin{tabular}{lllll} 
& $\mathrm{R}^{\top}$ & $\mathrm{R}^{2}$ & $\mathrm{R}^{3}$ & \multicolumn{1}{c}{$\mathrm{n}$} \\
\hline 46 & $\mathrm{SE} \mathrm{(B)}$ & $\mathrm{SEM}$ & $\mathrm{TCE}$ & $0(\mathrm{SAc})$ \\
47 & $\mathrm{SE}(B)$ & $\mathrm{SEM}$ & $\mathrm{TCE}$ & 8 \\
48 & $\mathrm{SE}(B)$ & $\mathrm{SEM}$ & $\mathrm{TCE}$ & 16 \\
49 & $\mathrm{H}$ & $\mathrm{H}$ & $\mathrm{TCE}$ & $0(\mathrm{SAC})$ \\
50 & $\mathrm{H}$ & $\mathrm{H}$ & $\mathrm{TCE}$ & 8 \\
51 & $\mathrm{H}$ & $\mathrm{H}$ & $\mathrm{TCE}$ & 16 \\
52 & $\mathrm{H}$ & $\mathrm{H}$ & $\mathrm{H}$ & $0(\mathrm{SAC})$ \\
53 & $\mathrm{H}$ & $\mathrm{H}$ & $\mathrm{H}$ & 8 \\
54 & $\mathrm{H}$ & $\mathrm{H}$ & $\mathrm{H}$ & 16
\end{tabular}
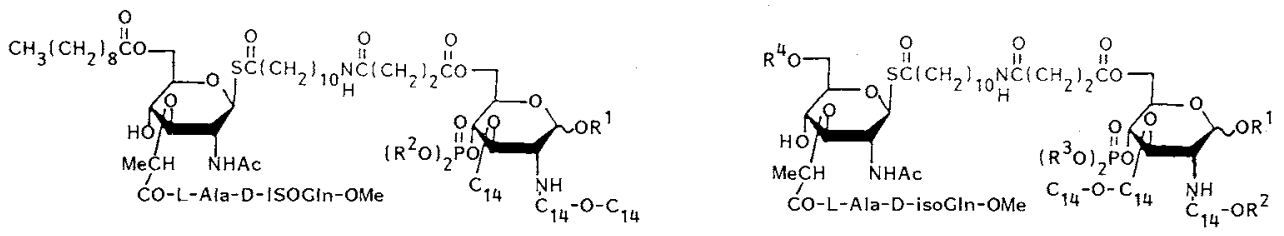

\begin{tabular}{llc} 
& $\mathrm{R}^{1}$ & $\mathrm{R}^{2}$ \\
\hline 55 & $\mathrm{SE}(B)$ & TCE \\
56 & $\mathrm{H}$ & TCE \\
57 & $\mathrm{H}$ & $\mathrm{H}$
\end{tabular}

\begin{tabular}{lcccc} 
& $R^{1}$ & $R^{2}$ & $R^{3}$ & $R^{4}$ \\
\hline 58 & SE (B) & SEM & TCE & $\mathrm{H}$ \\
59 & $\mathrm{SE}(B)$ & $\mathrm{SEM}$ & $\mathrm{TCE}$ & $\left.\mathrm{CH}_{3} i \mathrm{CH}_{2}\right)_{8} \mathrm{C}(\mathrm{O})$ \\
60 & $\mathrm{SE}(\mathrm{B})$ & $\mathrm{SEM}$ & $\mathrm{TCE}$ & $\mathrm{CH}_{3}\left(\mathrm{CH}_{2}\right)_{16} \mathrm{C}(\mathrm{O})$ \\
61 & $\mathrm{H}$ & $\mathrm{H}$ & $\mathrm{TCE}$ & $\mathrm{H}$ \\
62 & $\mathrm{H}$ & $\mathrm{H}$ & $\mathrm{TCE}$ & $\mathrm{CH}_{3}\left(\mathrm{CH}_{2}\right)_{8} \mathrm{C}(\mathrm{O})$ \\
63 & $\mathrm{H}$ & $\mathrm{H}$ & $\mathrm{TCE}$ & $\mathrm{CH}_{3}\left(\mathrm{CH}_{2}\right)_{16} \mathrm{C}(\mathrm{O})$ \\
64 & $\mathrm{H}$ & $\mathrm{H}$ & $\mathrm{H}$ & $\mathrm{H}$ \\
65 & $\mathrm{H}$ & $\mathrm{H}$ & $\mathrm{H}$ & $\left.\mathrm{CH}_{3}\left(\mathrm{CH}_{2}\right)_{8} \mathrm{ClO}\right)$ \\
66 & $\mathrm{H}$ & $\mathrm{H}$ & $\mathrm{H}$ & $\mathrm{CH}_{3}\left(\mathrm{CH}_{2}\right)_{16} \mathrm{C}(0)$
\end{tabular}

yields, respectively.

The tert-butoxycarbonyl group of $6 \sim 8$ and 14 $\sim 16$ was removed with trifluoroacetic acid at $0^{\circ} \mathrm{C}$ to afford the corresponding trifluoroacetate derivatives $(9 \sim 11$ and $17 \sim 19)$.

In view of the known propensity of divalent sulfur compounds for poisoning a catalytichydrogenation system, the hydroxyl groups of the lipid A moiety were suitably protected with 2-(trimethylsilyl)ethyl ${ }^{11)}$ and 2-(trimethylsilyl)ethoxymethyl $^{12)}$ groups, which are easily removable with Lewis acid. ${ }^{13)}$

The formation of 2-(trimethylsilyl)ethyl glycoside was accomplished by the oxazoline method. 2-Acetamido-1,3,4,6-tetra-O-acetyl- 2-deoxy- $\beta$-D-glucopyranose ${ }^{14)}$ (20) was converted with anhydrous ferric chloride to the oxazoline intermediate, which was then treated with 2-(trimethylsilyl)ethanol in the presence of conc. sulfuric acid at room temperature to give 2-(trimethylsilyl)ethyl 2-acetamido-3,4,6tri- $O$-acetyl-2-deoxy- $\beta$-D-glucopyranoside (21) in a good yield.

$O$-Deacetylation of 21 and 4,6-O-isopropylidenation were performed in the usual way, and hydrolytic removal of the $N$-acetyl group with barium hydroxide octahydrate in waterethanol under reflux gave 2-(trimethylsilyl)ethyl 2-amino-2-deoxy-4,6- $O$-isopropylidene$\beta$-D-glucopyranoside (22) in a $92 \%$ yield 
(based on 21). Treatment of 22 with (3R)-3hydroxytetradecanoic acid or (3R)-3-[2-(trimethylsilyl)ethoxymethoxy]tetradecanoic acid in the presence of 1-ethyl-3-(3-dimethylaminopropyl)carbodiimide hydrochloride (water-soluble carbodiimide, WSC) gave $2-\mathrm{N}$-acylated compounds (23 and 25) in $84 \%$ and $82 \%$ yields, respectively.

The remaining hydroxyl groups of $\mathbf{2 3}$ were simultaneously esterified with tetradecanoyl chloride and DMAP in pyridine to afford $\mathbf{2 4}$. Compound 26 was obtained by esterifying 25 with tetradecanoyloxytetradecanoic acid, WSC and DMAP. Compounds 24 and 26 were treated with aqueous acetic acid to remove the 4,6-O-isopropylidene group. The tert-butyldimethylsilyl group was introduced at $0-6$, and the resulting $\mathbf{2 8}$ and $\mathbf{3 3}$ were phosphorylated with bis(2,2,2-trichloroethyl)phosphoro chloridate to afford 29 and 34 in $84 \%$ and $78 \%$ yields, respectively.

The tert-butyldimethylsilyl group of $\mathbf{2 9}$ and 34 was cleaved with aqueous acetic acid to give 30 and 35 , and these were treated with succinic anhydride in the presence of DMAP in 1,2dichloroethane at room temperature to afford the 6-O-(3-carboxypropanoyl) derivatives (31 and 36 ).

Compounds 31 and 36 were coupled with the 1-thio-MDP methyl ester trifluoroacetate derivatives $(9 \sim 11$ and $17 \sim 19)$, using $N$-hydroxysuccinimide and DCC as the activating reagents, to give the protected coupling products $(37 \sim 39,46 \sim 48,55$ and $58 \sim 60)$. Removal of the silyl groups with boron trifluoride etherate in dichloromethane afforded $\mathbf{4 0} \sim \mathbf{4 2}$, $49 \sim 51,56$ and $61 \sim 63$. Finally, the bis(2,2,2trichloroethyl) groups were cleaved with zinc dust to yield the desired analogs $(\mathbf{4 3} \sim \mathbf{4 5}$, $52 \sim 54,57$ and $64 \sim 66$ ) as colorless powders, respectively.

The immunoadjuvant activities of the conjugates thus obtained for inducing the delayed type of hypersensitivity (DTH) to $N$-acetyl-Ltyrosine-3-azobenzene-4'-arsonate (ABA-Nacetyltyrosine) in guinea-pigs were examined (see Table I) ${ }^{15)}$ All of the compounds showed strong DTH activity, comparable to that of
Table I. ADJuvant Activity of SOME CONJUGATES ON THE INDUCTION OF DELAYED-TYPE HYPERSENSITIVITY TO ABA- $N$-ACETYLTYROSINE IN GUINEA-PIGS

\begin{tabular}{ccc}
\hline & $\begin{array}{c}\text { Skin reaction with ABA-BSA } \\
\text { Compound }\end{array}$ & $(100 \mu \mathrm{g})(\text { diam. in } \mathrm{mm} \pm \mathrm{SE})^{c}$ \\
& $24 \mathrm{hr}$ & $48 \mathrm{hr}$ \\
\hline $\mathbf{4 3}$ & $16.5 \pm 1.2$ & $12.3 \pm 1.9$ \\
$\mathbf{4 4}$ & $18.3 \pm 0.5$ & $15.8 \pm 1.2$ \\
$\mathbf{4 5}$ & $14.8 \pm 2.1$ & $12.8 \pm 2.5$ \\
$\mathbf{5 2}$ & $16.7 \pm 1.4$ & $(6.3 \pm 1.8)$ \\
$\mathbf{5 4}$ & $18.3 \pm 1.7$ & $12.5 \pm 3.0$ \\
$\mathbf{5 7}$ & $15.8 \pm 2.3$ & $10.0 \pm 3.4$ \\
$\mathbf{6 4}$ & $13.8 \pm 1.7$ & $(5.3 \pm 3.2)$ \\
$\mathbf{6 5}$ & $14.0 \pm 1.5$ & $6.5 \pm 2.4$ \\
$\mathbf{6 6}$ & $22.0 \pm 1.2$ & $16.3 \pm 1.0$ \\
MDP & $20.0 \pm 0.7$ & $19.0 \pm 0.7$ \\
Control & 0 & 0 \\
\hline
\end{tabular}

MDP at the same dose. In addition, we observed that these conjugates showed potent inducing activities for interleukin-1 and tumoricidal macrophages; especially, compounds $\mathbf{5 2}$ and 64 exhibited much higher activity than GLA60 (data not shown). These results indicate that these conjugates could have practical use as new biological response modifiers.

\section{Experimental}

Melting points (mp) were determined with Yanagimoto micromelting-point apparatus and are uncorrected. Specific rotations were determined with a Union PM-201 polarimeter, and IR spectra were recorded with a Jasco A100 spectrophotometer. ${ }^{1} \mathrm{H}-\mathrm{NMR}$ spectra were recorded with a Jeol JNM-GX270 spectrometer, using tetramethylsilane as an internal standard. Preparative chromatography on silica gel (Wako Co., 200 mesh) was accomplished with the solvent systems specified. Concentrations and evaporations were conducted in vacuo.

11-tert-Butoxycarbonylaminoundecanoic acid (2). To a 
mixture of 11-aminoundecanoic acid $(1 ; 3.0 \mathrm{~g}, 14.9 \mathrm{mmol})$ and triethylamine $(0.02 \mathrm{ml})$ in a mixture of water-1,4dioxane $(2: 1,30 \mathrm{ml})$ was added 2 -(tert-butoxycarbonylthio)-4,6-dimethylpyrimidine $(6.15 \mathrm{~g}, 25.6 \mathrm{mmol})$, and the mixture was stirred overnight at room temperature. The solvents were removed by lyophilization, and the residue was extracted with dichloromethane. The extract was washed with water, dried (sodium sulfate), and concentrated to a syrup, which was crystallized from hexane to give 2 ( $4.5 \mathrm{~g}$, quant.), $\mathrm{mp} 66^{\circ} \mathrm{C}$; IR $v_{\max }(\mathrm{KBr}) \mathrm{cm}^{-1}: 3320$ $(\mathrm{NH}), 2950$ and $2840(\mathrm{C}-\mathrm{H})$, and 1680 and 1510 (amide).

Anal. Found: C, 63.59; H, 10.48; N, 4.50. Calcd. for $\mathrm{C}_{16} \mathrm{H}_{31} \mathrm{NO}_{4}: \mathrm{C}, 63.76 ; \mathrm{H}, 10.37 ; \mathrm{N}, 4.65 \%$.

$N-[2-0-[2-A c e t a m i d o-1-S-a c e t y l-6-O-[11-($ tert-butoxycarbonylamino) undecanoyl]-2,3-dideoxy-1-thio- $\beta$-D-glucopyranose-3-yl]-D-lactoyl/-L-alanyl-D-isoglutamine methyl ester (6). A mixture of $\mathrm{N}$-[2-O-[2-acetamido-1-S-acetyl2,3-dideoxy-1-thio- $\beta$-D-glucopyranose-3-yl]-D-lactoyl]L-alanyl-D-isoglutamine methyl ester $(3 ; 100 \mathrm{mg}, 0.2 \mathrm{mmol})$, 1,4-dioxane-DMF (3:1, $2 \mathrm{ml})$, DCC (80 mg, $0.4 \mathrm{mmol})$, a catalytic amount of DMAP, and compound $2(12.6 \mathrm{mg}$, $0.4 \mathrm{mmol}$ ) was stirred for $5 \mathrm{hr}$ at room temperature. DC urea was removed by filtration and washed with 1,4 dioxane. The filtrate and washings were combined and concentrated. The residue was extracted with dichloromethane, and the extract was successively washed with $2 \mathrm{M}$ hydrochloric acid and water, dried (sodium sulfate), and concentrated to a syrup, which was chromatographed on a column of silica gel with dichloromethane-methanol $(30: 1)$ to give compound $6(73.5 \mathrm{mg}, 48 \%), \mathrm{mp} 146.5 \sim$ $148^{\circ} \mathrm{C},[\alpha]_{\mathrm{D}}+14.9^{\circ}(c=1.9,2: 1$ dichloromethane-methanol); IR $v_{\max }($ film $) \mathrm{cm}^{-1}: 3300(\mathrm{OH}, \mathrm{NH}), 2940$ and 2850 $(\mathrm{C}-\mathrm{H}), 1750$ (ester), 1700 (AcS), and 1650 and 1550 (amide); NMR $\left(\mathrm{CDCl}_{3}\right) \delta: 1.2 \sim 1.5(\mathrm{~m}, 31 \mathrm{H}$, lac-Me, alaMe, tert-Boc, and $\left.-\mathrm{CH}_{2}-\right), 1.94(\mathrm{~s}, 3 \mathrm{H}, \mathrm{AcN}), 2.34(\mathrm{~s}, 3 \mathrm{H}$, $\mathrm{AcS}), 2.44\left(\mathrm{~m}, 2 \mathrm{H},-\mathrm{COCH}_{2}-\right), 3.11\left(\mathrm{~m}, 2 \mathrm{H},-\mathrm{NHCH}_{2}-\right.$ ), $3.68(\mathrm{~s}, 3 \mathrm{H}, \mathrm{MeO})$, and $5.19\left(\mathrm{~d}, 1 \mathrm{H}, J_{1,2}=10.6 \mathrm{~Hz}, \mathrm{H}-1\right)$.

Anal. Found: C, 53.96; H, 7.95; N, 8.46. Calcd. for $\mathrm{C}_{38} \mathrm{H}_{65} \mathrm{~N}_{5} \mathrm{O}_{14} \mathrm{~S}: \mathrm{C}, 53.82 ; \mathrm{H}, 7.73 ; \mathrm{N}, 8.26 \%$.

N-[2-O-[2-Acetamido-6-O-[11-(tert-butoxycarbonylamino) undecanoyl]-1-S-decanoyl-2,3-dideo $x y-1-$ thio- $\beta$-Dglucopyranose-3-yl]-D-lactoyl]-L-alanyl-D-isoglutamine methyl ester ( 7 ). Compound 7 was obtained as crystals in a $57 \%$ yield by a condensation of $N-[2-O-[2$-acetamido- $1-S-$ decanoyl-2,3-dideoxy-1-thio- $\beta$-D-glucopyranose-3-yl]-Dlactoyl]-L-alanyl-D-isoglutamine methyl ester 4 with 2 , according to the method described for $6 ; \mathrm{mp} 152 \sim 155^{\circ} \mathrm{C}$, $[\alpha]_{\mathrm{D}}+6.6^{\circ}(c=2.9$, dichloromethane $) ;$ IR $v_{\max }(\mathrm{film}) \mathrm{cm}^{-1}$ : $3300(\mathrm{OH}, \mathrm{NH}), 2950$ and $2860(\mathrm{C}-\mathrm{H}), 1750$ (ester), 1690 $\left(S\right.$-acyl), and 1670 and 1540 (amide); NMR $\left(\mathrm{CDCl}_{3}\right) \delta$ : $0.87(\mathrm{t}, 3 \mathrm{H}, \mathrm{Me}), 1.26 \sim 1.44(\mathrm{~m}, 45 \mathrm{H}$, lac-Me, ala-Me, tert-Boc, and $\left.-\mathrm{CH}_{2}-\right), 1.92(\mathrm{~s}, 3 \mathrm{H}, \mathrm{AcN}), 3.67(\mathrm{~s}, 3 \mathrm{H}$, $\mathrm{MeO})$, and $5.14\left(\mathrm{~d}, 1 \mathrm{H}, J_{1,2}=10.6 \mathrm{~Hz}, \mathrm{H}-1\right)$.

Anal. Found: C, 57.28; H, 8.75; N, 7.20. Calcd. for $\mathrm{C}_{46} \mathrm{H}_{81} \mathrm{~N}_{5} \mathrm{O}_{14} \mathrm{~S}: \mathrm{C}, 57.54 ; \mathrm{H}, 8.50 ; \mathrm{N}, 7.29 \%$.
N-[2-O-[2-Acetamido-6-O-[1]-(tert-butoxycarbonylamino)undecanoyl $]-2,3-$ dideoxy-1-S-octadecanoyl-1-thio$\beta$-D-glucopyranose-3-yl]-D-lactoyl]-L-alanyl-D-isoglutamine methyl ester (8). Compound 8 was obtained as crystals in a $70 \%$ yield by coupling $N$-[2-O-[2-acetamido2,3-dideoxy-1-S-octadecanoyl-1-thio- $\beta$-D-glucopyranose3-yl]-D-lactoyl]-L-alanyl-D-isoglutamine methyl ester 5 with compound 2 , as described for $6 ; \mathrm{mp} 164.5 \sim 169^{\circ} \mathrm{C}$, $[\alpha]_{\mathrm{D}}+8.2^{\circ}(c=1 . .6$, dichloromethane); the IR and NMR spectra were consistent with the structures assigned.

Anal. Found: C, 60.59; H, 9.01; N, 6.33. Calcd. for $\mathrm{C}_{54} \mathrm{H}_{97} \mathrm{~N}_{5} \mathrm{O}_{14} \mathrm{~S}: \mathrm{C}, 60.48 ; \mathrm{H}, 9.12 ; \mathrm{N}, 6.53 \%$.

N-[2-O-[2-Acetamido-I-S-acetyl-6-O-(11-aminoundecanoyl)-2,3-dideoxy-1-thio- $\beta$-D-glucopyranose-3-yl]D-lactoyl]-L-alanyl-D-isoglutamine methyl ester triftuoroacetate (9). A mixture of $6(70 \mathrm{mg}, 0.08 \mathrm{mmol})$ and trifluoroacetic acid $(2 \mathrm{ml})$ was stirred for $1 \mathrm{hr}$ at $0^{\circ} \mathrm{C}$, and then the solvent was evaporated. The residual syrup was dissolved in 1,4-dioxane, and the dioxane was removed by lyophilization to leave 9 (71 $\mathrm{mg}$, quant.) as an amorphous solid; $[\alpha]_{\mathrm{D}}+12.5^{\circ}\left(c=1.9\right.$, ethanol); IR $v_{\max }(\mathrm{KBr})$ $\mathrm{cm}^{-1}: 3300(\mathrm{OH}, \mathrm{NH}), 2950$ and $2860(\mathrm{C}-\mathrm{H}), 1730$ (ester), 1690 (AcS), 1660 and 1530 (amide), and 1200, 1180 and 1140 (C-F).

Anal. Found: C, 48.98; H, 6.51; N, 7.96. Calcd. for $\mathrm{C}_{35} \mathrm{H}_{58} \mathrm{~N}_{5} \mathrm{O}_{14} \mathrm{~F}_{3} \mathrm{~S}: \mathrm{C}, 48.77 ; \mathrm{H}, 6.78 ; \mathrm{N}, 8.13 \%$.

The trifluoroacetates of other 6-O-(11-aminoundecanoyl) compounds (10 and 11). Compounds 10 and 11 were obtained quantitatively as amorphous solids, according to the procedure described for 9.

Compound 10 had $[\alpha]_{\mathrm{D}}+12.8^{\circ}(c=1.6$, methanol $)$; the IR data were similar to those of 9 .

Anal. Found: C, 53.31; H, 7.29; N, 7.05. Calcd. for $\mathrm{C}_{43} \mathrm{H}_{74} \mathrm{~N}_{5} \mathrm{O}_{14} \mathrm{~F}_{3} \mathrm{~S}: \mathrm{C}, 53.02 ; \mathrm{H}, 7.66 ; \mathrm{N}, 7.19 \%$.

Compound 11 had $\mathrm{mp} 135 \sim 138^{\circ} \mathrm{C}$ and $[\alpha]_{\mathrm{D}}+12.0^{\circ}$ ( $c=2.0,1: 1$ dichloromethane-methanol); the IR data were similar to those of 9.

Anal. Found: C, 56.58; H, 8.11; N, 6.28. Calcd. for $\mathrm{C}_{51} \mathrm{H}_{90} \mathrm{~N}_{5} \mathrm{O}_{14} \mathrm{~F}_{3} \mathrm{~S}: \mathrm{C}, 56.39 ; \mathrm{H}, 8.35 ; \mathrm{N}, 6.45 \%$.

N-[2-O-[2-Acetamido-1-S-[1]-(tert-butoxycarbonylamino) undecanoyl $]-2,3$-dideoxy-4,6-O-isopropylidene-1thio- $\beta$-D-glucopyranose-3-yl]-D-lactoyl]-L-alanyl-D-isoglutamine methyl ester (13). To a solution of $\mathrm{N}-[2-\mathrm{O}-$ - (2acetamido-1-S-acetyl-2,3-dideoxy-4,6- $O$-isopropylidene1-thio- $\beta$-D-glucopyranose-3-yl)-D-lactoyl]-L-alanyl-D-isoglutamine methyl ester $(12 ; 500 \mathrm{mg}, 0.84 \mathrm{mmol})$ in methanol was added an excess amount of metallic sodium $(50 \mathrm{mg})$ at $-25^{\circ} \mathrm{C}$. The mixture was stirred for $20 \mathrm{~min}$ at the same temperature, and then treated with Amberlite IR-120 $\left(\mathrm{H}^{+}\right)$resin to deionize the solution. The resin was filtered off and washed with methanol, and the filtrate and washings were combined and concentrated. The resulting product was treated with $2(360 \mathrm{mg}, 1.2 \mathrm{mmol})$ in the presence of DCC $(340 \mathrm{mg}, 1.7 \mathrm{mmol})$ in 1,4-dioxane $(5 \mathrm{ml})$. 
The mixture was stirred for $2 \mathrm{hr}$ at room temperature, and DC urea was filtered off and washed with 1,4-dioxane. The filtrate and washings were combined and concentrated to a syrup, which was chromatographed on a column of silica gel with dichloromethane-methanol $(50: 1)$ to give 13 as a solid $(480 \mathrm{mg}, 68 \%)$, mp $75 \sim 79^{\circ} \mathrm{C},[\alpha]_{\mathrm{D}}+11.7^{\circ}(c=0.5$, dichloromethane); IR $v_{\max }\left(\right.$ film) $\mathrm{cm}^{-1}: 3300(\mathrm{NH}), 2940$ and $2850(\mathrm{C}-\mathrm{H}), 1740$ (ester), $1700(S$-acyl), 1650 and 1550 (amide), and $860\left(\mathrm{Me}_{2} \mathrm{C}\right)$; NMR $\left(\mathrm{CDCl}_{3}\right) \delta: 1.25 \sim 1.49$ $\left(\mathrm{m}, 37 \mathrm{H}\right.$, lac-Me, ala-Me, tert-Boc, $-\mathrm{CH}_{2}-$, and $\mathrm{Me}_{2} \mathrm{C}$ ), 1.94 (s, 3H, AcN), 2.51 (m, 2H, $\left.-\mathrm{COCH}_{2}-\right), 3.12(\mathrm{~m}, 2 \mathrm{H}$, $\left.-\mathrm{NHCH}_{2}-\right), 3.70(\mathrm{~s}, 3 \mathrm{H}, \mathrm{MeO})$, and $5.24\left(\mathrm{~d}, 1 \mathrm{H}, J_{1,2}=\right.$ $10.6 \mathrm{~Hz}, \mathrm{H}-1)$.

Anal. Found: C, 55.18; H, 7.77; N, 8.06. Calcd. for $\mathrm{C}_{39} \mathrm{H}_{67} \mathrm{~N}_{5} \mathrm{O}_{13} \mathrm{~S}: \mathrm{C}, 55.37 ; \mathrm{H}, 7.98 ; \mathrm{N}, 8.28 \%$.

N-[2-O-[2-Acetamido-1-S-[1]-(tert-butoxycarbonylamino) undecanoyl]-2,3-dideoxy-1-thio- $\beta$-D-glucopyranose3-y1]-D-lactoyl]-L-alanyl-D-isoglutamine methyl ester (14). A solution of $13(450 \mathrm{mg}, 0.53 \mathrm{mmol})$ in $80 \%$ aqueous acetic acid $(5 \mathrm{ml})$ was stirred for $2 \mathrm{hr}$ at $45^{\circ} \mathrm{C}$, and then concentrated. The residue was dissolved in 1,4-dioxane and the solvent was removed by lyophilization, leaving 14 as a solid (425 mg, quant.), mp $110 \sim 111.5^{\circ} \mathrm{C},[\alpha]_{D}+24.6^{\circ}$ ( $c=0.6,1: 1$ dichloromethane-methanol); IR $v_{\max }(\mathrm{KBr})$ $\mathrm{cm}^{-1}: 3300(\mathrm{OH}, \mathrm{NH}), 2980$ and $2850(\mathrm{C}-\mathrm{H}), 1740$ (ester), 1700 ( $S$-acyl), and 1650 and 1550 (amide).

Anal. Found: C, 53.38; H, 7.66; N, 8.41. Calcd. for $\mathrm{C}_{36} \mathrm{H}_{63} \mathrm{~N}_{5} \mathrm{O}_{13} \mathrm{~S}: \mathrm{C}, 53.65 ; \mathrm{H}, 7.88 ; \mathrm{N}, 8.69 \%$.

$N-[2-0-[2-A c e t a m i d o-I-S-[11-(t e r t-b u t o x y c a r b o n y l-$ amino) undecanoyl J-6-O-decanoyl-2,3-dideoxy-1-thio- $\beta$-Dglucopyranose-3-yl]-D-lactoyl]-L-alanyl-D-isoglutamine methyl ester (15). Compound 14 ( $200 \mathrm{mg}, 0.25 \mathrm{mmol})$ in 1,4-dioxane-DMF (10:1,3 ml) was treated with decanoic acid $(55.6 \mathrm{mg}, 0.32 \mathrm{mmol})$ in the presence of DCC $(180 \mathrm{mg}$, $0.89 \mathrm{mmol}$ ) and DMAP (a catalytic amount), and the mixture was worked up as described for $\mathbf{6}$ to give $\mathbf{1 5}$ (204 mg, 86\%), mp $141 \sim 144^{\circ} \mathrm{C},[\alpha]_{\mathrm{D}}+7.9^{\circ}(c=1.9$, dichloromethane); IR $v_{\max }(\mathrm{film}) \mathrm{cm}^{-1}: 3300(\mathrm{OH}, \mathrm{NH})$, 2950 and $2860(\mathrm{C}-\mathrm{H}), 1750$ (ester), 1690 ( $S$-acyl), and 1670 and 1540 (amide); NMR $\left(\mathrm{CDCl}_{3}\right) \delta: 0.88$ (t, 3H, acyl-Me), $1.26 \sim 1.44(\mathrm{~m}, 45 \mathrm{H}$, lac-Me, ala-Me, tert-Boc, and $\left.-\mathrm{CH}_{2}-\right), 1.92(\mathrm{~s}, 3 \mathrm{H}, \mathrm{AcN}), 3.62(\mathrm{~s}, 3 \mathrm{H}, \mathrm{MeO})$, and $5.14(\mathrm{~d}$, $\left.1 \mathrm{H}, J_{1,2}=10.6 \mathrm{~Hz}, \mathrm{H}-1\right)$.

Anal. Found: C, 57.71; $\mathrm{H}, 8.76 ; \mathrm{N}, 7.44$. Calcd. for $\mathrm{C}_{46} \mathrm{H}_{81} \mathrm{~N}_{5} \mathrm{O}_{14} \mathrm{~S}: \mathrm{C}, 57.54 ; \mathrm{H}, 8.50 ; \mathrm{N}, 7.29 \%$.

$\mathrm{N}-[$ 2-O-[2-Acetamido-1-S[1]-(tert-butoxycarbonylamino)undecanoyl $]$-2,3-dideoxy-6-O-octadecanoyl-1-thio$\beta$-D-glucopyranose-3-yl]-D-lactoyl]-L-alanyl-D-isoglutamine methyl ester (16). Compound 16 was obtained in a $65 \%$ yield as described for 15 .

Compound 16 had $\mathrm{mp} 150 \sim 150.5^{\circ} \mathrm{C}$ and $[\alpha]_{\mathrm{D}}+14.5^{\circ}$ $(c=2.5,1: 1$ dichloromethane-methanol); the IR and NMR data were consistent with the structures assigned.

Anal. Found: C, $60.59 ; \mathrm{H}, 9.11 ; \mathrm{N}, 6.41$. Calcd. for
$\mathrm{C}_{54} \mathrm{H}_{97} \mathrm{~N}_{5} \mathrm{O}_{14} \mathrm{~S}: \mathrm{C}, 60.48 ; \mathrm{H}, 9.12 ; \mathrm{N}, 6.53 \%$

Trifluoroacetates of $1-S(1 /$-aminoundecanoyl) derivatives (17, 18 and 19). Compounds 17, 18 and 19 were each obtained in quantitative yields as described for 9

Compound 17 had $[\alpha]_{\mathrm{D}}+13.9^{\circ}(c=0.2$, ethanol $)$.

Anal. Found: C, 48.36; H, 6.77; N, 8.39. Calcd. for $\mathrm{C}_{33} \mathrm{H}_{56} \mathrm{~N}_{5} \mathrm{O}_{13} \mathrm{~F}_{3} \mathrm{~S}: \mathrm{C}, 48.34 ; \mathrm{H}, 6.88 ; \mathrm{N}, 8.54 \%$.

Compound 18 had $\mathrm{mp} 84 \sim 86.5^{\circ} \mathrm{C}$ and $[\alpha]_{\mathrm{D}}+23.0^{\circ}$ ( $c=4.4$, methanol).

Anal. Found: C, 52.93; H, 7.40; N, 6.99. Calcd. for $\mathrm{C}_{43} \mathrm{H}_{74} \mathrm{~N}_{5} \mathrm{O}_{14} \mathrm{~F}_{3} \mathrm{~S}: \mathrm{C}, 53.02 ; \mathrm{H}, 7.66 ; \mathrm{N}, 7.19 \%$.

Compound 19 had mp $156.5 \sim 157.5^{\circ} \mathrm{C}$ and $[\alpha]_{\mathrm{D}}+16.3^{\circ}$ $(c=1.1,1: 1$ dichloromethane-methanol).

Anal. Found: $\mathrm{C}, 56.28 ; \mathrm{H}, 8.50 ; \mathrm{N}, 6.03$. Calcd. for $\mathrm{C}_{53} \mathrm{H}_{92} \mathrm{~N}_{5} \mathrm{O}_{15} \mathrm{~F}_{3} \mathrm{~S}: \mathrm{C}, 56.41 ; \mathrm{H}, 8.22 ; \mathrm{N}, 6.21 \%$.

2-(Trimethylsilyl)ethyl 2-acetamido-3,4,6-tri-O-acetyl-2deoxy- $\beta$-D-glucopyranoside (21). To a solution of 2 -acetamido-1,3,4-6-tetra- $O$-acetyl-2-deoxy- $\beta$-D-glucopyranose $(20 ; 4.0 \mathrm{~g}, 10.3 \mathrm{mmol})$ in dichloromethane $(50 \mathrm{ml})$ was added anhydrous ferric chloride $(3.2 \mathrm{~g}, 19.7 \mathrm{mmol})$, and the mixture was vigorously stirred for $1.5 \mathrm{hr}$ at room temperature. Sodium hydrogen carbonate was added to neutralize the solution, and the precipitates were filtered off and washed with dichloromethane. The filtrate and washings were combined, washed with water, dried (sodium sulfate), and concentrated. The resulting oxazoline was treated with 2-(trimethylsilyl)ethanol $(1.77 \mathrm{~g}, 15 \mathrm{mmol})$ and a catalytic amount of conc. sulfuric acid in dichloromethane $(50 \mathrm{ml})$; stirring was continued overnight at room temperature. The mixture was washed with $1 \mathrm{M}$ sodium hydrogen carbonate and water, dried (sodium sulfate) and evaporated. The residue was chromatographed on a column of silica gel with dichloromethane-methanol (400:1). The product was crystallized from hexane to afford 21 $(4.3 \mathrm{~g}, 96 \%)$ : mp $152 \sim 155^{\circ} \mathrm{C},[\alpha]_{\mathrm{D}}-7.7^{\circ}(c=0.8$, dichloromethane); IR $v_{\max }$ (film) $\mathrm{cm}^{-1}: 3280(\mathrm{NH}), 1740$ (ester), 1650 and 1560 (amide), and 860 and 830 ( $\mathrm{Si}-\mathrm{C}$ ); NMR $\left(\mathrm{CDCl}_{3}\right) \delta: 0.0\left(\mathrm{~s}, 9 \mathrm{H}, \mathrm{Me}_{3} \mathrm{Si}\right), 0.87\left(\mathrm{~m}, 2 \mathrm{H}, \mathrm{SiMe}_{3}-\mathrm{CH}_{2}-\right)$, $1.88,1.96,1.97$, and $2.03(4 \mathrm{~s}, 12 \mathrm{H}, \mathrm{Ac}), 3.50(\mathrm{~m}, 1 \mathrm{H}$, $\left.\mathrm{SiMe}_{3}-\mathrm{CH}_{2}-\mathrm{CH}_{\mathrm{a}}-\right), 3.64(\mathrm{~m}, 1 \mathrm{H}, \mathrm{H}-5), 3.69\left(\mathrm{q}, 1 \mathrm{H}, J_{1,2}=\right.$ $\left.J_{2,3}=J_{2, \mathrm{NH}}=8.8 \mathrm{~Hz}, \mathrm{H}-2\right), 3.90\left(\mathrm{~m}, 1 \mathrm{H}, \mathrm{SiMe}_{3}-\mathrm{CH}_{2}\right.$ $\mathrm{CH}_{\mathrm{b}}-$ ), 4.06 (br. s, $1 \mathrm{H}, \mathrm{H}-6_{\mathrm{a}}$ ), 4.21 (dd, $1 \mathrm{H}, J_{\text {gem }}=12 \mathrm{~Hz}$, $\left.J_{5,6 \mathrm{~b}}=4.7 \mathrm{~Hz}, \mathrm{H}-6_{\mathrm{b}}\right), 4.67\left(\mathrm{~d}, 1 \mathrm{H}, J_{1,2}=8.4 \mathrm{~Hz}, \mathrm{H}-1\right), 5.00$ $\left(\mathrm{t}, 1 \mathrm{H}, J_{3,4}=J_{4,5}=10 \mathrm{~Hz}, \mathrm{H}-3\right)$, and $5.48\left(\mathrm{~d}, 1 \mathrm{H}, J_{2, \mathrm{NH}}=\right.$ $8.8 \mathrm{~Hz}, \mathrm{NH})$.

Anal. Found: C, $50.84 ; \mathrm{H}, 7.63 ; \mathrm{N}, 3.09$. Calcd. for $\mathrm{C}_{19} \mathrm{H}_{33} \mathrm{NO}_{9} \mathrm{Si}: \mathrm{C}, 50.99 ; \mathrm{H}, 7.43 ; \mathrm{N}, 3.13 \%$.

2-(Trimethylsilyl)ethyl 2-amino-2-deoxy-4,6-O-isopropylidene- $\beta$-D-glucopyranoside (22). To a solution of $21(4 \mathrm{~g}$. $8.9 \mathrm{mmol})$ in methanol $(100 \mathrm{ml})$ was added sodium methoxide in methanol ( $28 \%$ soln., $1 \mathrm{ml}$ ), and the mixture was stirred for $30 \mathrm{~min}$ at room temperature. Amberlite IR-120 $\left(\mathrm{H}^{+}\right)$resin was added to deionize the solution, and then the resin was filtered off and washed with methanol. The 
filtrate and washings were combined and concentrated. The resulting 2-(trimethylsilyl)ethyl 2-acetamido-2-deoxy$\beta$-D-glucopyranoside was dissolved in DMF $(100 \mathrm{ml})$ and treated with 2,2-dimethoxypropane $(10 \mathrm{ml})$ in the presence of a catalytic amount of $p$-toluenesulfonic acid monohydrate for $1 \mathrm{hr}$ at room temperature. Sodium methoxide in methanol $(28 \%$ soln., $1 \mathrm{ml})$ was added, and then the solvent was evaporated. The residue was treated with barium hydroxide octahydrate $(6 \mathrm{~g}, 19 \mathrm{mmol})$ in waterethanol $(2: 1,120 \mathrm{ml})$ for 2 days under refluxing conditions. The product was extracted with chloroform, before the organic layer was washed with water, dried (sodium sulfate) and concentrated to a syrup, which was chromatographed on a column of silica gel with dichloromethane-methanol $(100: 1)$. The product was dissolved in 1,4-dioxane and the dioxane was removed by lyophilization, leaving $22(2.6 \mathrm{~g}, 92 \%)$ as a solid, $\mathrm{mp}$ $110 \sim 111^{\circ} \mathrm{C},[\alpha]_{\mathrm{D}}-59.0^{\circ} \quad(c=0.5$, dichloromethane); IR $v_{\text {max }}($ film $) \mathrm{cm}^{-1}: 3400(\mathrm{OH}, \mathrm{NH}), 1580\left(\mathrm{NH}_{2}\right)$, and 850 $\left(\mathrm{Si}-\mathrm{C}, \mathrm{Me}_{2} \mathrm{C}\right) ; \mathrm{NMR}\left(\mathrm{CDCl}_{3}\right) \delta: 0.0\left(\mathrm{~s}, 9 \mathrm{H}, \mathrm{Me}_{3} \mathrm{Si}\right), 1.00$ $\left(\mathrm{m}, 2 \mathrm{H}, \mathrm{Me}_{3} \mathrm{Si}-\mathrm{CH}_{2}-\right), 1.40$ and $1.48\left(2 \mathrm{~s}, 6 \mathrm{H}, \mathrm{Me}_{2} \mathrm{C}\right), 1.92$ (br. s, 3H, OH and $\mathrm{NH}_{2}$ ), $2.71(\mathrm{t}, 1 \mathrm{H}, J=8 \mathrm{~Hz}, \mathrm{H}-2), 3.23$ (m, $1 \mathrm{H}, \mathrm{H}-5), 3.4 \sim 3.6\left(\mathrm{~m}, 3 \mathrm{H}, \mathrm{Me}_{3} \mathrm{Si}-\mathrm{CH}_{2}-\mathrm{CH}_{\mathrm{a}}-\mathrm{H}-3\right.$ and 4), $3.78\left(\mathrm{t}, 1 \mathrm{H}, J_{\text {gem }}=J_{5,6 \mathrm{a}}=10 \mathrm{~Hz}, \mathrm{H}-6_{\mathrm{a}}\right), 3.89(\mathrm{dd}$, $\left.1 \mathrm{H}, J_{\mathrm{gem}}=10 \mathrm{~Hz}, J_{5.6 \mathrm{~b}}=5.5 \mathrm{~Hz}, \mathrm{H}-6_{\mathrm{b}}\right), 3.95(\mathrm{~m}, 1 \mathrm{H}$, $\mathrm{Me}_{3} \mathrm{Si}-\mathrm{CH}_{2}-\mathrm{CH}_{\mathrm{b}}-$ ), and $4.21\left(\mathrm{~d}, 1 \mathrm{H}, J_{1,2}=8 \mathrm{~Hz}, \mathrm{H}-1\right)$.

Anal. Found: C, 52.47; H, 9.21; N, 4.12. Calcd. for $\mathrm{C}_{14} \mathrm{H}_{29} \mathrm{NO}_{5} \mathrm{Si}: \mathrm{C}, 52.63 ; \mathrm{H}, 9.15 ; \mathrm{N}, 4.38 \%$.

2-(Trimethylsilyl)ethyl 2-deoxy-2-/(3R)-3-hydroxytetradecanamido ]-4,6-O-isopropylidene- $\beta$-D-glucopyranoside (23). A mixture of $22(2.6 \mathrm{~g}, 8.1 \mathrm{mmol}),(3 R)-3$ hydroxytetradecanoic acid $(2.4 \mathrm{~g}, 9.8 \mathrm{mmol})$ and WSC $(4.0 \mathrm{~g}, 20.9 \mathrm{mmol})$ in dichloromethane $(100 \mathrm{ml})$ was stirred overnight at room temperature, before the reaction mixture was chromatographed on a column of silica gel with dichloromethane-methanol $(150: 1)$ to give $23(3.7 \mathrm{~g}, 84 \%)$ as a syrup: $[\alpha]_{\mathrm{D}}-40^{\circ}(c=1.8$, dichloromethane $)$, IR $y_{\max }$ (film) $\mathrm{cm}^{-1}: 3300(\mathrm{OH}, \mathrm{NH}), 2950$ and $2850(\mathrm{C}-\mathrm{H}), 1640$ and 1550 (amide), and 860 ( $\mathrm{Si}-\mathrm{C}, \mathrm{Me}_{2} \mathrm{C}$ ); NMR ( $\mathrm{CDCl}_{3}$ ) $\delta: 0.0\left(\mathrm{~s}, 9 \mathrm{H}, \mathrm{Me}_{3} \mathrm{Si}\right), 0.9\left(\mathrm{~m}, 5 \mathrm{H}, \mathrm{Me}_{3} \mathrm{Si}-\mathrm{CH}_{2}-\right.$ and $\left.\mathrm{Me}\right)$, $1.2 \sim 1.6\left(\mathrm{~m}, 20 \mathrm{H},-\mathrm{CH}_{2}-\right), 1.41$ and $1.50\left(2 \mathrm{~s}, 6 \mathrm{H}, \mathrm{Me}_{2} \mathrm{C}\right)$, $2.2 \sim 2.5\left(\mathrm{~m}, 2 \mathrm{H},-\mathrm{COCH}_{2}-\right), 4.83\left(\mathrm{~d}, 1 \mathrm{H}, J_{1,2}=8.4 \mathrm{~Hz}, \mathrm{H}-\right.$ 1), and 6.50 (br.s, $1 \mathrm{H}, \mathrm{NH}$ ).

Anal. Found: C, 61.33; H, 10.78; N, 2.36. Calcd. for $\mathrm{C}_{28} \mathrm{H}_{55} \mathrm{NO}_{7} \mathrm{Si}: \mathrm{C}, 61.61 ; \mathrm{H}, 10.61 ; \mathrm{N}, 2.57 \%$.

2-(Trimethylsilyl)ethyl 2-deoxy-4,6-O-isopropylidene-3O-tetradecanoyl-2-[(3R)-3-tetradecanoyloxytetradecanamido - $\beta$-D-glucopyranoside (24). To a solution of 23 $(3.5 \mathrm{~g}, 6.9 \mathrm{mmol})$ and DMAP $(1.3 \mathrm{~g}, 10.7 \mathrm{mmol})$ in pyridine $(50 \mathrm{ml})$ was added tetradecanoyl chloride $(5.1 \mathrm{~g}, 20.7$ mmol), before the mixture was stirred overnight at room temperature. Methanol was added to decompose the excess reagent, and the solvent was evaporated. The residue was extracted with chloroform, and the extract was washed with $2 \mathrm{M}$ hydrochloric acid and water, dried (sodium sulfate) and concentrated to a syrup, which was chromatographed on a column of silica gel with dichloromethane. The title compound $\mathbf{2 4}(6.2 \mathrm{~g}, 92 \%)$ was dissolved.in 1,4-dioxane and lyophilized to leave a solid, $\mathrm{mp}$ $47.5^{\circ} \mathrm{C},[\alpha]_{\mathrm{D}}-17.1^{\circ}\left(c=3.7\right.$, dichloromethane); IR $v_{\max }$ (film) $\mathrm{cm}^{-1}$ : $3400(\mathrm{OH}, \mathrm{NH}), 2930$ and $2850(\mathrm{C}-\mathrm{H}), 1740$ (ester), 1650 and 1520 (amide), and 860 and 840 ( $\mathrm{Si}-\mathrm{C}$, $\left.\mathrm{Me}_{2} \mathrm{C}\right) ; \mathrm{NMR}\left(\mathrm{CDCl}_{3}\right) \delta: 0.0\left(\mathrm{~s}, 9 \mathrm{H}, \mathrm{Me}_{3} \mathrm{Si}\right), 0.9(\mathrm{~m}, 11 \mathrm{H}$, $\mathrm{Me}_{3} \mathrm{Si}-\mathrm{CH}_{2}-$ and $\left.\mathrm{Me}\right), 1.1 \sim 1.7\left(\mathrm{~m}, 64 \mathrm{H},-\mathrm{CH}_{2}-\right), 1.36$ and $1.46\left(2 \mathrm{~s}, 6 \mathrm{H}, \mathrm{Me}_{2} \mathrm{C}\right), 2.2 \sim 2.5\left(\mathrm{~m}, 6 \mathrm{H},-\mathrm{COCH}_{2}-\right)$, $3.35(\mathrm{~m}, 1 \mathrm{H}, \mathrm{H}-5), 3.55\left(\mathrm{~m}, 1 \mathrm{H}, \mathrm{Me}_{3} \mathrm{Si}-\mathrm{CH}_{2}-\mathrm{CH}_{\mathrm{a}}-\right.$ ), $3.65 \sim 4.05\left(\mathrm{~m}, 5 \mathrm{H}, \mathrm{H}-2,4,6\right.$, and $\left.\mathrm{Me}_{3} \mathrm{Si}-\mathrm{CH}_{2}-\mathrm{CH}_{\mathrm{b}}-\right), 4.53$ $\left(\mathrm{d}, 1 \mathrm{H}, J_{1,2}=8 \mathrm{~Hz}, \mathrm{H}-1\right), 5.05\left(\mathrm{~m}, 2 \mathrm{H}, \mathrm{H}-3\right.$ of $\mathrm{C}_{14}-\mathrm{O}-\mathrm{C}_{14}$ and $\mathrm{H}-3$ ), and 6.05 (br., $1 \mathrm{H}, \mathrm{NH}$ ).

Anal. Found: C, $69.39 ; \mathrm{H}, 11.28 ; \mathrm{N}, 1.26$. Calcd. for $\mathrm{C}_{56} \mathrm{H}_{107} \mathrm{NO}_{9} \mathrm{Si}: \mathrm{C}, 69.59 ; \mathrm{H}, 11.16 ; \mathrm{N}, 1.45 \%$.

2-(Trimethylsilyl)ethyl 2-deoxy-4,6-O-isopropylidene-2$[(3 R)-3-[2-($ trime thylsilyl)ethoxymethoxy]tetradecanamidoJ- $\beta$-D-glucopyranoside (25). To a solution of $\mathbf{2 2}$ $(2.0 \mathrm{~g}, 6.3 \mathrm{mmol})$ in dichloromethane $(30 \mathrm{ml})$ was added (3R)-3-[2-(trimethylsilyl)ethoxymethoxy]tetradecanoic acid $\left\{[\alpha]_{\mathrm{D}}-1.4^{\circ} \quad(c=0.8\right.$, dichloromethane $), 2.98 \mathrm{~g}, 8.0$ mmol $\}$ and $\operatorname{WSC}(2.4 \mathrm{~g}, 12.6 \mathrm{mmol})$. The mixture was stirred overnight at room temperature, and processed as described for 23 , to give $25(3.6 \mathrm{~g}, 82 \%)$, mp $74 \sim 75.5^{\circ} \mathrm{C}$, $[\alpha]_{\mathrm{D}}-32.8^{\circ}\left(c=1.3\right.$, dichloromethane); IR $v_{\max }(\mathrm{KBr})$ $\mathrm{cm}^{-1}: 3490(\mathrm{OH}), 3300(\mathrm{NH}), 2930$ and $2850(\mathrm{C}-\mathrm{H}), 1640$ and 1550 (amide), and 860 and 840 ( $\mathrm{Si}-\mathrm{C}, \mathrm{Me}_{2} \mathrm{C}$ ); NMR $\left(\mathrm{CDCl}_{3}\right) \delta: 0.0\left(\mathrm{~s}, 18 \mathrm{H}, \mathrm{Me}_{3} \mathrm{Si}\right), 0.85\left(\mathrm{~m}, 7 \mathrm{H}, \mathrm{Me}_{3} \mathrm{Si}_{-} \mathrm{CH}_{2}-\right.$ and $\mathrm{Me}), 1.2 \sim 1.6\left(\mathrm{~m}, 20 \mathrm{H},-\mathrm{CH}_{2}\right), 3.2 \sim 4.0(\mathrm{~m}, 11 \mathrm{H}$, $\mathrm{Me}_{3} \mathrm{Si}-\mathrm{CH}_{2}-\mathrm{CH}_{2}-, \mathrm{H}-2,3,4,5,6$ and $\mathrm{H}-3$ of $\mathrm{C}_{14}-\mathrm{OSEM}$ ), $4.7\left(\mathrm{~m}, 4 \mathrm{H},-\mathrm{OCH}_{2} \mathrm{O}-, \mathrm{H}-1\right.$, and $\left.\mathrm{OH}\right)$, and $6.44(\mathrm{~d}, 1 \mathrm{H}$, $J=5.5 \mathrm{~Hz}, \mathrm{NH})$.

Anal. Found: C, $60.17 ; \mathrm{H}, 10.63 ; \mathrm{N}, 1.98$. Calcd. for $\mathrm{C}_{34} \mathrm{H}_{69} \mathrm{NO}_{8} \mathrm{Si}_{2}: \mathrm{C}, 60.40 ; \mathrm{H}, 10.39 ; \mathrm{N}, 2.09 \%$.

2-(Trimethylsilyl)ethyl 2-deoxy-4,6-O-isopropylidene-3-O$[(3 R)$-3-tetradecanoyloxytetradecanoyl]-2- $[(3 R)-3-[2-($ irimethylsilyl )ethoxymethoxy $]$ tetradecanamido $-\beta-\mathrm{D}-g$ lucopyranoside (26). To a solution of $25(3.5 \mathrm{~g}, 5.2 \mathrm{mmol})$ in dichloromethane $(50 \mathrm{ml})$ were added $(3 R)$-3-tetradecanoyloxytetradecanoic acid $(3 \mathrm{~g}, 6.3 \mathrm{mmol})$, WSC $(2.0 \mathrm{~g}, 10.5$ $\mathrm{mmol}$ ) and DMAP (100 $\mathrm{mg}, 0.8 \mathrm{mmol})$, the mixture being stirred overnight at room temperature. The product was purified by chromatography on a column of silica gel with dichloromethane to afford 26 (5.8 g, quant.) as a syrup, $[\alpha]_{\mathrm{D}}-12.6^{\circ} \quad\left(c=0.8\right.$, dichloromethane); IR $v_{\max }$ (film) $\mathrm{cm}^{-1}: 3300(\mathrm{NH}), 2930$ and $2850(\mathrm{C}-\mathrm{H}), 1740$ (ester), 1650 and 1550 (amide), and 860 and 840 ( $\mathrm{Si}-\mathrm{C}, \mathrm{Me}_{2} \mathrm{C}$ ); NMR $\left(\mathrm{CDCl}_{3}\right) \delta: 0.0\left(\mathrm{~s}, 18 \mathrm{H}, \mathrm{Me}_{3} \mathrm{Si}\right), 0.85\left(\mathrm{~m}, 13 \mathrm{H}, \mathrm{Me}_{3} \mathrm{Si}-\right.$ $\mathrm{CH}_{2}-$ and $\left.\mathrm{Me}\right), 1.1 \sim 1.7\left(\mathrm{~m}, 62 \mathrm{H},-\mathrm{CH}_{2}-\right), 1.40$ and 1.49 . $\left(2 \mathrm{~s}, 6 \mathrm{H}, \mathrm{Me}_{2} \mathrm{C}\right), 2.2 \sim 2.5\left(\mathrm{~m}, 6 \mathrm{H},-\mathrm{COCH}_{2}-\right), 3.2 \sim 4.0(\mathrm{~m}$, $10 \mathrm{H}, \mathrm{Me}_{3} \mathrm{Si}-\mathrm{CH}_{2}-\mathrm{CH}_{2}-, \mathrm{H}-2,4,5,6$, and $\mathrm{H}-3$ of $\mathrm{C}_{14^{-}}$ OSEM), $4.45 \sim 4.65\left(\mathrm{~m}, 3 \mathrm{H},-\mathrm{OCH}_{2} \mathrm{O}-\right.$ and $\left.\mathrm{H}-1\right), 5.05(\mathrm{~m}$, $2 \mathrm{H}, \mathrm{H}-3$ of $\mathrm{C}_{14}-\mathrm{O}-\mathrm{C}_{14}$ and $\left.\mathrm{H}-3\right)$, and $6.28(\mathrm{~d}, 1 \mathrm{H}, J=$ $9.1 \mathrm{~Hz}, \mathrm{NH})$.

Anal. Found: C, 67.06; H, 11.03; N, 1.38. Calcd. for 
$\mathrm{C}_{62} \mathrm{H}_{12} \mathrm{NO}_{11} \mathrm{Si}_{2}: \mathrm{C}, 66.92 ; \mathrm{H}, 10.96 ; \mathrm{N}, 1.26 \%$.

2-(Trimethylsilyl)ethyl 2-deoxy-3-O-tetradecanoyl-2[(3R)-3-tetradecanoyloxytetradecanamido]- $\beta$-D-glucopyranoside (27). A mixture of $24(6.2 \mathrm{~g}, 6.4 \mathrm{mmol})$ and $80 \%$ aqueous acetic acid $(300 \mathrm{ml})$ was stirred for $3 \mathrm{hr}$ at $50^{\circ} \mathrm{C}$. The mixture was concentrated and chromatographed on a column of silica gel with dichloromethane-methanol $(100: 1)$ to give $27(5.2 \mathrm{~g}, 88 \%)$, which was lyophilized from 1,4-dioxane solution, $\mathrm{mp} 82 \sim 84^{\circ} \mathrm{C},[\alpha]_{\mathrm{D}}-12.3^{\circ}(c=$ 0.5 , dichloromethane); IR $v_{\max }(\mathrm{KBr}) \mathrm{cm}^{-1}: 3450(\mathrm{OH})$, $3300(\mathrm{NH}), 2900$ and $2850(\mathrm{C}-\mathrm{H}), 1720$ (ester), 1650 and 1550 (amide), and 850 and 830 (Si-C); NMR $\left(\mathrm{CDCl}_{3}\right) \delta$ : $0.0\left(\mathrm{~s}, 9 \mathrm{H}, \mathrm{Me}_{3} \mathrm{Si}\right), 0.87\left(\mathrm{~m}, 11 \mathrm{H}, \mathrm{Me}_{3} \mathrm{Si}-\mathrm{CH}_{2}-\right.$ and $\left.\mathrm{Me}\right)$, $1.1 \sim 1.7\left(\mathrm{~m}, 64 \mathrm{H},-\mathrm{CH}_{2}-\right), 2.1 \sim 2.5\left(\mathrm{~m}, 6 \mathrm{H},-\mathrm{COCH}_{2}-\right)$, $3.42(\mathrm{~m}, 1 \mathrm{H}, \mathrm{H}-5), 3.52\left(\mathrm{~m}, 1 \mathrm{H}, \mathrm{Me}_{3} \mathrm{Si}-\mathrm{CH}_{2}-\mathrm{CH}_{3}-\right), 3.71$ $\left(\mathrm{t}, 1 \mathrm{H}, J_{3,4}=J_{4,5}=9.3 \mathrm{~Hz}, \mathrm{H}-4\right), 3.75 \sim 3.95(\mathrm{~m}, 4 \mathrm{H}, \mathrm{H}-$ 2, 6, and $\mathrm{Me}_{3} \mathrm{Si}-\mathrm{CH}_{2}-\mathrm{CH}_{\mathrm{b}}-$ ), $4.61\left(\mathrm{~d}, 1 \mathrm{H}, J_{1,2}=8.3 \mathrm{~Hz}\right.$, $\mathrm{H}-1), 5.09\left(\mathrm{~m}, 2 \mathrm{H}, \mathrm{H}-3\right.$ of $\mathrm{C}_{14}-\mathrm{O}-\mathrm{C}_{14}$ and $\left.\mathrm{H}-3\right)$, and 6.06 (d, $1 \mathrm{H}, J=7.8 \mathrm{~Hz}, \mathrm{NH})$

Anal. Found: C, $68.48 ; \mathrm{H}, 11.43 ; \mathrm{N}, 1.72$. Calcd. for $\mathrm{C}_{53} \mathrm{H}_{103} \mathrm{NO}_{9} \mathrm{Si}: \mathrm{C}, 68.71 ; \mathrm{H}, 11.21 ; \mathrm{N}, 1.51 \%$

2-(Trimethylsilyl)ethyl 6-O-tert-butyldimethylsilyl-2-deoxy-3-O-tetradecanoyl-2-[(3R)-3-tetradecanoyloxytetradecanamido J- $\beta$-D-glucopyranoside (28). To a solution of $\mathbf{2 7}$ $(3.0 \mathrm{~g}, 3.2 \mathrm{mmol})$ in pyridine $(30 \mathrm{ml})$ was added tert-butyldimethylsilyl chloride ( $1 \mathrm{~g}, 6.7 \mathrm{mmol})$, before stirring overnight at room temperature. Methanol was added, and the solvent was then evaporated. The residue was chromatographed on a column of silica gel with dichloromethanemethanol $(400: 1)$ and lyophilized from 1,4-dioxane solution to afford $28(3.3 \mathrm{~g}, 98 \%), \mathrm{mp} 58.5^{\circ} \mathrm{C},[\alpha]_{\mathrm{D}}-16.4^{\circ}$ ( $c=3.8$, dichloromethane); IR $v_{\max }$ (film) $\mathrm{cm}^{-1}: 3450$ $(\mathrm{OH}), 3300(\mathrm{NH}), 2900$ and $2850(\mathrm{C}-\mathrm{H}), 1720$ and 1700 (ester), 1650 and 1550 (amide), and 830 (Si-C); NMR $\left(\mathrm{CDCl}_{3}\right) \delta: 0.0(\mathrm{~s}, 15 \mathrm{H}, \mathrm{Me}-\mathrm{Si}), 0.9\left(\mathrm{~m}, 20 \mathrm{H}, \mathrm{Me}_{3} \mathrm{Si}-\right.$ $\mathrm{CH}_{2}-$, tert $-\mathrm{Bu}$, and $\left.\mathrm{Me}\right), 1.1 \sim 1.7\left(\mathrm{~m}, 64 \mathrm{H},-\mathrm{CH}_{2}-\right.$ ), $2.1 \sim 2.5\left(\mathrm{~m}, 6 \mathrm{H},-\mathrm{COCH}_{2}-\right), 3.28($ br. $\mathrm{s}, 1 \mathrm{H}, \mathrm{OH}), 3.43(\mathrm{~m}$, $1 \mathrm{H}, \mathrm{H}-5), 3.55\left(\mathrm{~m}, 1 \mathrm{H}, \mathrm{Me}_{3} \mathrm{Si}-\mathrm{CH}_{2}-\mathrm{CH}_{\mathrm{a}}-\right), 3.70(\mathrm{t}, 1 \mathrm{H}$, $\left.J_{3,4}=J_{4.5}=9.2 \mathrm{~Hz}, \mathrm{H}-4\right), 3.8 \sim 4.0(\mathrm{~m}, 4 \mathrm{H}, \mathrm{H}-2,6$, and $\mathrm{Me}_{3} \mathrm{Si}_{-}-\mathrm{CH}_{2}-\mathrm{CH}_{\mathrm{b}}-$ ), $4.52\left(\mathrm{~d}, 1 \mathrm{H}, J_{1,2}=8.4 \mathrm{~Hz}, \mathrm{H}-1\right), 5.04$ $\left(\mathrm{m}, 2 \mathrm{H}, \mathrm{H}-3\right.$ of $\mathrm{C}_{14}-\mathrm{O}-\mathrm{C}_{14}$ and $\left.\mathrm{H}-3\right)$, and $5.83(\mathrm{~d}, 1 \mathrm{H}, J=$ $8.8 \mathrm{~Hz}, \mathrm{NH})$.

Anal. Found: C, 67.89; H, 11.48; N, 1.56. Calcd. for $\mathrm{C}_{59} \mathrm{H}_{117} \mathrm{NO}_{9} \mathrm{Si}_{2}: \mathrm{C}, 68.09 ; \mathrm{H}, 11.33 ; \mathrm{N}, 1.35 \%$.

2-(Trimethylsilyl)ethyl 4-O-[bis(2,2,2-trichloroethyl)phosphono -6-O-tert-butyldimethylsilyl-2-deoxy-3-O-tetradecanoyl-2-[(3R)-3-tetradecanoyloxytetradecanamido]- $\beta$ D-glucopyranoside (29). A mixture of $28(0.5 \mathrm{~g}, 0.5 \mathrm{mmol})$, dichloromethane $(5 \mathrm{ml}), N, N$-diisopropylethylamine $(0.6 \mathrm{~g}$, $4.6 \mathrm{mmol})$, a catalytic amount of DMAP, and bis $(2,2,2-$ trichloroethyl) phosphorochloridate $(0.75 \mathrm{~g}, 2 \mathrm{mmol})$ was stirred for $1 \mathrm{hr}$ at room temperature. The reaction mixture was extracted with chloroform, and the extract was successively washed with $2 \mathrm{M}$ hydrochloric acid and water, dried (sodium sulfate) and concentrated. The residual syrup was chromatographed on a column of silica gel with dichloromethane-methanol $(400: 1)$ to give $29(0.56 \mathrm{~g}$, $84 \%$ and lyophilized from 1,4-dioxane solution, mp 50 $52.5^{\circ} \mathrm{C},[\alpha]_{\mathrm{D}}-1.9^{\circ}\left(c=1.3\right.$, dichloromethane); IR $v_{\max }$ (film) $\mathrm{cm}^{-1}: 3300(\mathrm{NH}), 2900$ and $2830(\mathrm{C}-\mathrm{H}), 1740$ (ester), 1650 and 1550 (amide), $910\left(\mathrm{P}-\mathrm{O}-\mathrm{CH}_{2}\right), 860$ and $840(\mathrm{Si}-\mathrm{C})$, and $720(\mathrm{C}-\mathrm{Cl}) ; \mathrm{NMR}\left(\mathrm{CDCl}_{3}\right) \delta: 0.0(\mathrm{~s}, 15 \mathrm{H}$, $\mathrm{Me}-\mathrm{Si}), 0.9\left(\mathrm{~m}, 20 \mathrm{H}, \mathrm{Me}_{3} \mathrm{Si}_{-} \mathrm{C}_{2}{ }_{2}\right.$, tert-Bu, and $\mathrm{Me}$ ), $1.0 \sim 1.75\left(\mathrm{~m}, 64 \mathrm{H},-\mathrm{CH}_{2}-\right), 2.2 \sim 2.5\left(\mathrm{~m}, 6 \mathrm{H},-\mathrm{COCH}_{2}-\right)$, $4.45 \sim 4.75\left(\mathrm{~m}, 6 \mathrm{H}, \mathrm{H}-1,4\right.$, and $\left.\mathrm{CCl}_{3} \mathrm{CH}_{2}-\right), 5.00(\mathrm{~m}, 1 \mathrm{H}$, $\mathrm{H}-3$ of $\left.\mathrm{C}_{14}-\mathrm{O}-\mathrm{C}_{14}\right), 5.37\left(\mathrm{t}, 1 \mathrm{H}, J_{2,3}=J_{3,4}=9 \mathrm{~Hz}, \mathrm{H}-3\right)$, and $5.90(\mathrm{~d}, 1 \mathrm{H}, J=8.4 \mathrm{~Hz}, \mathrm{NH})$.

Anal. Found: C, $54.78 ; \mathrm{H}, 8.94 ; \mathrm{N}, 1.08$. Calcd. for $\mathrm{C}_{63} \mathrm{H}_{120} \mathrm{NO}_{12} \mathrm{Cl}_{6} \mathrm{PSi}_{2}: \mathrm{C}, 54.69 ; \mathrm{H}, 8.74 ; \mathrm{N}, 1.01 \%$.

2-(Trimethylsilyl)ethyl 4-O-[bis(2,2,2-trichloroethyl)phosphono]-2-deoxy-3-O-tetradecanoyl-2-[(3R)-3-tetradecanoyloxytetradecanamido $-\beta$-D-glucopyranoside (30). A mixture of $29(0.5 \mathrm{~g}, 0.4 \mathrm{mmol})$ and $80 \%$ aqueous acetic acid $(50 \mathrm{ml})$ was stirred for $3 \mathrm{hr}$ at $50^{\circ} \mathrm{C}$, before the solvent was evaporated. The residue was chromatographed on a column of silica gel with dichloromethane-methanol $(300: 1)$ to give $30(0.46 \mathrm{~g}, 75 \%)$, which was lyophilized from 1,4-dioxane solution, mp $69 \sim 71^{\circ} \mathrm{C},[\alpha]_{\mathrm{D}}-5.4^{\circ}(c=$ 0.3 , dichloromethane); IR $v_{\max }(\mathrm{film}) \mathrm{cm}^{-1}: 3450(\mathrm{OH})$, $3300(\mathrm{NH}), 2920$ and $2850(\mathrm{C}-\mathrm{H}), 1740$ (ester), 1650 and 1550 (amide), $920\left(\mathrm{P}-\mathrm{O}-\mathrm{CH}_{2}\right), 860$ and $840(\mathrm{Si}-\mathrm{C})$, and $720(\mathrm{C}-\mathrm{Cl}) ; \mathrm{NMR}\left(\mathrm{CDCl}_{3}\right) \delta: 0.0\left(\mathrm{~s}, 9 \mathrm{H}, \mathrm{Me}_{3} \mathrm{Si}\right), 0.9(\mathrm{~m}$, $11 \mathrm{H}, \mathrm{Me}_{3} \mathrm{Si}-\mathrm{CH}_{2}-$ and $\left.\mathrm{Me}\right), 1.1 \sim 1.75\left(\mathrm{~m}, 64 \mathrm{H},-\mathrm{CH}_{2}-\right)$, $2.2 \sim 2.5\left(\mathrm{~m}, 6 \mathrm{H},-\mathrm{COCH}_{2}-\right), 2.64($ br., $1 \mathrm{H}, \mathrm{OH}), 3.5(\mathrm{~m}$, $2 \mathrm{H}, \mathrm{Me}_{3} \mathrm{Si}-\mathrm{CH}_{2}-\mathrm{CH}_{\mathrm{a}}-$ and $\left.\mathrm{H}-5\right), 3.70\left(\mathrm{q}, 1 \mathrm{H}, J_{1,2}=J_{2,3}=\right.$ $J_{2, \mathrm{NH}}=8 \mathrm{~Hz}, \mathrm{H}-2$ ), 3.94 (br. s, $3 \mathrm{H}, \mathrm{Me}_{3} \mathrm{Si}-\mathrm{CH}_{2}-\mathrm{CH}_{\mathrm{b}}-$ and $\mathrm{H}-6), 4.65\left(\mathrm{~m}, 5 \mathrm{H}, \mathrm{CCl}_{3} \mathrm{CH}_{2}\right.$ - and $\left.\mathrm{H}-4\right), 4.80\left(\mathrm{~d}, 1 \mathrm{H}, J_{1,2}=\right.$ $8.4 \mathrm{~Hz}, \mathrm{H}-1), 4.99\left(\mathrm{~m}, 1 \mathrm{H}, \mathrm{H}-3\right.$ of $\left.\mathrm{C}_{14}-\mathrm{O}-\mathrm{C}_{14}\right), 5.48(\mathrm{t}, 1 \mathrm{H}$, $J_{2,3}=J_{3,4}=9.1 \mathrm{~Hz}, \mathrm{H}-3$ ), and 6.09 (br. s, $1 \mathrm{H}, \mathrm{NH}$ ).

Anal. Found: C, $54.10 ; \mathrm{H}, 8.66 ; \mathrm{N}, 0.95$. Calcd. for $\mathrm{C}_{57} \mathrm{H}_{106} \mathrm{NO}_{12} \mathrm{Cl}_{6} \mathrm{PSi}$ : C, 53.94; H, 8.42; N, $1.10 \%$.

2-(Trimethylsilyl)ethyl 4-O-lbis(2,2,2-trichloroethyl)phosphonol $]-6-O-(3-$ carboxypropanoyl)-2-deoxy-3-O-tetradecanoyl-2-[(3R)-3-tetradecanoyloxytetradecanamido]$\beta$-D-glucopyranoside (31). To a solution of $30(0.23 \mathrm{~g}$, $0.2 \mathrm{mmol}$ ) and DMAP (a catalytic amount) in 1,2-dichloroethane $(4 \mathrm{ml})$ was added succinic anhydride $(0.16 \mathrm{~g}$, $1.6 \mathrm{mmol}$ ). The mixture was stirred for $1.5 \mathrm{hr}$ at room temperature, and extracted with chloroform. The extract was washed with $2 \mathrm{M}$ hydrochloric acid and water, dried (sodium sulfate), and concentrated. The residue was chromatographed on a column of silica gel with dichloromethane-methanol (200:1) to afford $\mathbf{3 1}$ as a syrup $(0.21$ $\mathrm{g}, 84 \%),[\alpha]_{\mathrm{D}}-1.7^{\circ}(c=0.8$, dichloromethane $) ;$ IR $v_{\max }$ (film) $\mathrm{cm}^{-1}: 3350(\mathrm{NH}), 2900$ and $2800(\mathrm{C}-\mathrm{H}), 300 \sim$ $2400(\mathrm{COOH}), 1750$ and $1720(\mathrm{C}=\mathrm{O}), 1650$ and 1540 (amide), $920\left(\mathrm{P}-\mathrm{O}-\mathrm{CH}_{2}\right), 860(\mathrm{Si}-\mathrm{C})$, and $730(\mathrm{C}-\mathrm{Cl})$; NMR $\left(\mathrm{CDCl}_{3}\right) \delta: 0.0\left(\mathrm{~s}, 9 \mathrm{H}, \mathrm{Me}_{3} \mathrm{Si}\right), 0.9\left(\mathrm{~m}, 11 \mathrm{H}, \mathrm{Me}_{3} \mathrm{Si}-\right.$ $\mathrm{CH}_{2}-$ and $\left.\mathrm{Me}\right), 1.0 \sim 1.75\left(\mathrm{~m}, 64 \mathrm{H},-\mathrm{CH}_{2}-\right), 2.2 \sim 2.5(\mathrm{~m}$, $\left.6 \mathrm{H},-\mathrm{COCH}_{2}-\right), 2.68\left(\mathrm{~s}, 4 \mathrm{H},-\mathrm{CO}\left(\mathrm{CH}_{2}\right)_{2} \mathrm{CO}-\right), 3.55(\mathrm{~m}$, 
$1 \mathrm{H}, \mathrm{Me}_{3}-\mathrm{CH}_{2}-\mathrm{CH}_{-}-$), $3.75(\mathrm{~m}, 2 \mathrm{H}, \mathrm{H}-2$ and 5), $3.90(\mathrm{~m}$, $\left.1 \mathrm{H}, \mathrm{Me}_{3} \mathrm{Si}-\mathrm{CH}_{2}-\mathrm{CH}_{\mathrm{b}}-\right), 4.27\left(\mathrm{dd}, 1 \mathrm{H}, J_{\mathrm{gem}}=12 \mathrm{~Hz}\right.$, $\left.J_{5,6 \mathrm{a}}=4.4 \mathrm{~Hz}, \mathrm{H}-6_{\mathrm{a}}\right), 4.60\left(\mathrm{~m}, 6 \mathrm{H}, \mathrm{H}-4,6_{\mathrm{b}}\right.$, and $\left.\mathrm{CCl}_{3} \mathrm{CH}_{2}-\right)$, $4.73\left(\mathrm{~d}, 1 \mathrm{H}, J_{1,2}=8.4 \mathrm{~Hz}, \mathrm{H}-1\right), 4.99(\mathrm{~m}, 1 \mathrm{H}, \mathrm{H}-3$ of $\left.\mathrm{C}_{14}-\mathrm{O}-\mathrm{C}_{14}\right), 5.41\left(\mathrm{t}, 1 \mathrm{H}, J_{2,3}=J_{3,4}=10 \mathrm{~Hz}, \mathrm{H}-3\right)$, and 6.09 (d, $1 \mathrm{H}, J=8.4 \mathrm{~Hz}, \mathrm{NH}$ ).

Anal. Found: C, 53.38; H, 8.34; N, 1.13. Calcd. for $\mathrm{C}_{61} \mathrm{H}_{110} \mathrm{NO}_{15} \mathrm{Cl}_{6} \mathrm{PSi}: \mathrm{C}, 53.51 ; \mathrm{H}, 8.10 ; \mathrm{N}, 1.02 \%$.

2-(Trimethylsilyl)ethyl 4-O-[bis(2,2,2-trichloroethyl)phosphono ]-6-O-tert-butyldimethylsilyl-2-deoxy-3-O$[(3 R)$-3-tetradecanoyloxytetradecanoyl]-2-[(3R)-3-[2-(trimethylsilyl)ethoxymethoxy 7 tetradecanamido $]-\beta$-D-glucopyranoside (34). A mixture of $26(5.8 \mathrm{~g}, 5.2 \mathrm{mmol})$ and $80 \%$ aqueous acetic acid $(300 \mathrm{ml})$ was treated in the usual manner to give $32(4.5 \mathrm{~g}, 78 \%),[\alpha]_{\mathrm{D}}-3.3^{\circ}(c=0.12$, dichloromethane); IR $v_{\max }$ (film) $\mathrm{cm}^{-1}: 3300(\mathrm{OH}, \mathrm{NH})$, 2930 and 2850 (C-H), 1740 (ester), 1650 and 1550 (amide), and 860 and $840(\mathrm{Si}-\mathrm{C})$; NMR $\left(\mathrm{CDCl}_{3}\right) \delta: 0.0(\mathrm{~s}, 18 \mathrm{H}$, $\left.\mathrm{Me}_{3} \mathrm{Si}\right), 0.85\left(\mathrm{~m}, 13 \mathrm{H}, \mathrm{Me}_{3} \mathrm{Si}-\mathrm{CH}_{2}-\right.$ and $\left.\mathrm{Me}\right), 1.1 \sim 1.7(\mathrm{~m}$, $\left.62 \mathrm{H},-\mathrm{CH}_{2}-\right), 2.1 \sim 2.5\left(\mathrm{~m}, 6 \mathrm{H},-\mathrm{COCH}_{2}-\right), 3.3 \sim 3.9(\mathrm{~m}$, $10 \mathrm{H}, \mathrm{Me}_{3} \mathrm{Si}-\mathrm{CH}_{2}-\mathrm{CH}_{2}-, \mathrm{H}-2,4,5$, and $\mathrm{H}-3$ of $\mathrm{C}_{14}-$ OSEM), $4.5 \sim 4.7\left(\mathrm{~m}, 3 \mathrm{H},-\mathrm{OCH}_{2} \mathrm{O}-\right.$ and $\left.\mathrm{H}-1\right), 4.99(\mathrm{t}, 1 \mathrm{H}$, $\left.J_{2,3}=J_{3,4}=9.1 \mathrm{~Hz}, \mathrm{H}-3\right), 5.05\left(\mathrm{~m}, 1 \mathrm{H}, \mathrm{H}-3\right.$ of $\left.\mathrm{C}_{14}-\mathrm{O}-\mathrm{C}_{14}\right)$, and $6.28(\mathrm{~d}, 1 \mathrm{H}, J=9.2 \mathrm{~Hz}, \mathrm{NH})$.

Anal. Found: C, 66.11; H, 11.15; N, 1.20. Calcd. for $\mathrm{C}_{59} \mathrm{H}_{117} \mathrm{NO}_{11} \mathrm{Si}_{2}: \mathrm{C}, 66.06 ; \mathrm{H}, 10.99 ; \mathrm{N}, 1.31 \%$.

Compound $32(2.7 \mathrm{~g}, 2.5 \mathrm{mmol})$ was treated with tertbutyldimethylsilyl chloride $(0.75 \mathrm{~g}, 5 \mathrm{mmol})$ in pyridine $(30 \mathrm{ml})$ overnight at room temperature, as described for 28 , to give $33\left(2.85 \mathrm{~g}, 94^{\circ}\right), \mathrm{mp} 38 \sim 39^{\circ} \mathrm{C},[\alpha]_{\mathrm{D}}-6.2^{\circ}(\mathrm{c}=$ 0.45 , dichloromethane); IR $v_{\max }$ (film) $\mathrm{cm}^{-1}: 3400(\mathrm{OH})$, $3300(\mathrm{NH}), 2930$ and $2850(\mathrm{C}-\mathrm{H}), 1740$ (ester), 1650 and 1550 (amide), and 860 and $840(\mathrm{Si}-\mathrm{C})$; NMR $\left(\mathrm{CDCl}_{3}\right) \delta$ : $0.0(\mathrm{~s}, 24 \mathrm{H}, \mathrm{Me}-\mathrm{Si}), 0.7 \sim 1.0\left(\mathrm{~m}, 22 \mathrm{H}, \mathrm{Me}_{3} \mathrm{Si}_{-}-\mathrm{CH}_{2}-\right.$ and Me), $1.1 \sim 1.7\left(\mathrm{~m}, 62 \mathrm{H},-\mathrm{CH}_{2}-2.2 \sim 2.6(\mathrm{~m}, 6 \mathrm{H}\right.$, $\left.-\mathrm{COCH}_{2}-\right), 3.3 \sim 3.9\left(\mathrm{~m}, 11 \mathrm{H}, \mathrm{Me}_{3} \mathrm{Si}-\mathrm{CH}_{2}-\mathrm{CH}_{2}-, \mathrm{H}-2,4\right.$, $5,6, \mathrm{H}-3$ of $\mathrm{C}_{14}-\mathrm{OSEM}$, and $\left.\mathrm{OH}\right), 4.45\left(\mathrm{~d}, 1 \mathrm{H}, J_{1,2}=\right.$ $8.4 \mathrm{~Hz}, \mathrm{H}-1), 4.61\left(2 \mathrm{~d}, 2 \mathrm{H}, J_{\mathrm{gem}}=7 \mathrm{~Hz},-\mathrm{OCH}_{2} \mathrm{O}-\right), 4.95(\mathrm{t}$, $\left.1 \mathrm{H}, J_{2,3}=J_{3,4}=9.1 \mathrm{~Hz}, \mathrm{H}-3\right), 5.08\left(\mathrm{~m}, 1 \mathrm{H}, \mathrm{H}-3\right.$ of $\mathrm{C}_{14}-\mathrm{O}$ $\left.\mathrm{C}_{14}\right)$, and $6.09(\mathrm{~d}, 1 \mathrm{H}, J=9.2 \mathrm{~Hz}, \mathrm{NH})$.

Anal. Found: C, $65.52 ; \mathrm{H}, 11.01 ; \mathrm{N}, 0.93$. Calcd. for $\mathrm{C}_{65} \mathrm{H}_{131} \mathrm{NO}_{11} \mathrm{Si}_{3}: \mathrm{C}, 65.77 ; \mathrm{H}, 11.12 ; \mathrm{N}, 1.18 \%$.

Compound $33(0.3 \mathrm{~g}, 0.3 \mathrm{mmol})$ was phosphorylated with bis(2,2,2-trichloroethyl) phosphorochloridate $(0.38 \mathrm{~g}$, $1 \mathrm{mmol}), N, N$-diisopropylethylamine $(0.2 \mathrm{~g}, 1.5 \mathrm{mmol})$, and a catalytic amount of DMAP in dichloromethane $(10 \mathrm{ml})$, as described for 29 , to afford $34(0.32 \mathrm{~g}, 83 \%),[\alpha]_{\mathrm{D}}$ $+5.0^{\circ} \quad\left(c=1.2\right.$, dichloromethane); IR $v_{\max }($ film $) \mathrm{cm}^{-1}$ : $3300(\mathrm{NH}), 2930$ and $2850(\mathrm{C}-\mathrm{H}), 1740$ (ester), 1650 and 1540 (amide), $910\left(\mathrm{P}-\mathrm{O}-\mathrm{CH}_{2}\right), 860$ and $840(\mathrm{Si}-\mathrm{C})$, and $800 \sim 720(\mathrm{C}-\mathrm{Cl}) ; \mathrm{NMR}\left(\mathrm{CDCl}_{3}\right) \delta: 0.0(\mathrm{~m}, 24 \mathrm{H}, \mathrm{Me}-\mathrm{Si})$, $0.8 \sim 1.0\left(\mathrm{~m}, 22 \mathrm{H}, \mathrm{Me}_{3} \mathrm{Si}-\mathrm{CH}_{2}-\right.$ and $\left.\mathrm{Me}\right), 1.1 \sim 1.7(\mathrm{~m}$, $\left.62 \mathrm{H},-\mathrm{CH}_{2}-\right), 2.25$ and $2.6\left(2 \mathrm{~m}, 6 \mathrm{H},-\mathrm{COCH}_{2}-\right), 3.45 \sim$ 3.75 and $3.8 \sim 4.0\left(2 \mathrm{~m}, 9 \mathrm{H}, \mathrm{Me}_{3} \mathrm{Si}-\mathrm{CH}_{2}-\mathrm{CH}_{2}-\mathrm{H}-2,5,6\right.$, and $\mathrm{H}-3$ of $\mathrm{C}_{14}$ OSEM), $4.41\left(\mathrm{q}, 1 \mathrm{H}, J_{3,4}=J_{4,5}=J_{4, \mathrm{P}}=9.2\right.$ $\mathrm{Hz}, \mathrm{H}-4), 4.5 \sim 4.75\left(\mathrm{~m}, 6 \mathrm{H},-\mathrm{OCH}_{2} \mathrm{O}-\right.$ and $\left.\mathrm{CCl}_{3} \mathrm{CH}_{2}-\right)$, $4.93\left(\mathrm{~d}, 1 \mathrm{H}, J_{1,2}=8.4 \mathrm{~Hz}, \mathrm{H}-1\right), 5.19(\mathrm{~m}, 1 \mathrm{H}, \mathrm{H}-3$ of $\left.\mathrm{C}_{14}-\mathrm{O}-\mathrm{C}_{14}\right), 5.50\left(\mathrm{t}, 1 \mathrm{H}, J_{2,3}=J_{3,4}=9.2 \mathrm{~Hz}, \mathrm{H}-3\right)$, and $6.36(\mathrm{~d}, 1 \mathrm{H}, J=8.1 \mathrm{~Hz}, \mathrm{NH})$.

Anal. Found: C, 54.41; H, 8.53; N, 1.03. Calcd. for $\mathrm{C}_{69} \mathrm{H}_{134} \mathrm{NO}_{14} \mathrm{Cl}_{6} \mathrm{PSi}_{3}$ : C, 54.17; H, 8.83; N, 0.92\%

2-(Trimethylsilyl)ethyl 4-O-[bis(2,2,2-trichloroethyl)phosphono ]-6-O-(3-carboxypropanoyl)-2-deoxy-3-O$[(3 R)$-3-tetradecanoyloxytetradecanoyl $]-2-[(3 R)-3-[2-($ trimethylsilyl)ethoxymethoxy] tetradecanamido $]-\beta$-D-glucopyranoside (36). Compound $34(0.43 \mathrm{~g}, 0.3 \mathrm{mmol})$ was treated with $80 \%$ aqueous acetic acid $(100 \mathrm{ml})$ at $50^{\circ} \mathrm{C}$, as described for 30, to give $35(0.34 \mathrm{~g}, 86 \%),[\alpha]_{\mathrm{D}}+2.1^{\circ}(c=$ 0.75 , dichloromethane); IR $v_{\max }(\mathrm{film}) \mathrm{cm}^{-1}: 3450(\mathrm{OH})$, $3300(\mathrm{NH}), 2930$ and $2850(\mathrm{C}-\mathrm{H}), 1740$ (ester), 1650 and 1550 (amide), $910\left(\mathrm{P}-\mathrm{O}-\mathrm{CH}_{2}\right), 860$ and $840(\mathrm{Si}-\mathrm{C})$, and $800 \sim 720(\mathrm{C}-\mathrm{Cl})$; NMR $\left(\mathrm{CDCl}_{3}\right) \delta: 0.0\left(\mathrm{~m}, 18 \mathrm{H}, \mathrm{Me}_{3} \mathrm{Si}\right)$, $0.7 \sim 0.95\left(\mathrm{~m}, 13 \mathrm{H}, \mathrm{Me}_{3} \mathrm{Si}-\mathrm{CH}_{2}-\right.$ and $\left.\mathrm{Me}\right), 1.1 \sim 1.8(\mathrm{~m}$, $\left.62 \mathrm{H},-\mathrm{CH}_{2}-\right), 2.25$ and $2.55\left(2 \mathrm{~m}, 6 \mathrm{H},-\mathrm{COCH}_{2}-\right), 2.83$ (br. s, $\mathrm{lH}, \mathrm{OH}$ ), $3.4 \sim 3.65$ and $3.75 \sim 3.95\left(2 \mathrm{~m}, 9 \mathrm{H}, \mathrm{Me}_{3} \mathrm{Si}-\right.$ $\mathrm{CH}_{2}-\mathrm{CH}_{2}-\mathrm{H}-2,5,6$, and $\mathrm{H}-3$ of $\left.\mathrm{C}_{14}-\mathrm{OSEM}\right), 4.45 \sim 4.65$ (m, $7 \mathrm{H}, \mathrm{H}-4,-\mathrm{OCH}_{2} \mathrm{O}-$, and $\left.\mathrm{CCl}_{3} \mathrm{CH}_{2}-\right), 4.92(\mathrm{~d}, 1 \mathrm{H}$, $\left.J_{1,2}=8 \mathrm{~Hz}, \mathrm{H}-1\right), 5.12\left(\mathrm{~m}, 1 \mathrm{H}, \mathrm{H}-3\right.$ of $\left.\mathrm{C}_{14}-\mathrm{O}-\mathrm{C}_{14}\right), 5.47(\mathrm{t}$, $\left.1 \mathrm{H}, J_{2,3}=J_{3,4}=9.2 \mathrm{~Hz}, \mathrm{H}-3\right)$, and $6.43(\mathrm{~d}, 1 \mathrm{H}, J=8 \mathrm{~Hz}$, NH).

Anal. Found: C, 53.58; H, 8.34; N, 0.75. Calcd. for $\mathrm{C}_{63} \mathrm{H}_{120} \mathrm{NO}_{14} \mathrm{Cl}_{6} \mathrm{PSi}_{2}: \mathrm{C}, 53.46 ; \mathrm{H}, 8.55 ; \mathrm{N}, 0.99 \%$.

A mixture of compound $35(0.5 \mathrm{~g}, 0.4 \mathrm{mmol})$ and succinic anhydride $(0.35 \mathrm{~g}, 3.5 \mathrm{mmol})$ in the presence of DMAP in 1,2-dichloroethane $(8 \mathrm{ml})$ was processed as described for 12 to afford $17(0.5 \mathrm{~g}, 95 \%),[\alpha]_{\mathrm{D}}+7.4^{\circ}$ ( $c=1.1$, dichloromethane); IR $v_{\max }$ (film) $\mathrm{cm}^{-1}: 3300$ $(\mathrm{NH}), 2930$ and $2850(\mathrm{C}-\mathrm{H}), 3400 \sim 2400(\mathrm{COOH}), 1740$ and 1720 (ester), 1650 and 1550 (amide), $910\left(\mathrm{P}-\mathrm{O}-\mathrm{CH}_{2}\right)$, 860 and $840(\mathrm{Si}-\mathrm{C})$, and $800 \sim 720(\mathrm{C}-\mathrm{Cl})$; NMR $\left(\mathrm{CDCl}_{3}\right)$ $\delta: 0.0\left(\mathrm{~s}, 18 \mathrm{H}, \mathrm{Me}_{3} \mathrm{Si}\right), 0.8 \sim 1.0\left(\mathrm{~m}, 13 \mathrm{H}, \mathrm{Me}_{3} \mathrm{Si}-\mathrm{CH}_{2}-\right.$ and $\mathrm{Me}), 1.1 \sim 1.7\left(\mathrm{~m}, 62 \mathrm{H},-\mathrm{CH}_{2}-\right), 2.2 \sim 2.35(\mathrm{~m}, 4 \mathrm{H}$, $\left.\mathrm{COCH}_{2}-\right), 2.66\left[\right.$ br.s, $6 \mathrm{H},-\mathrm{COCH}_{2}-$ and $-\mathrm{CO}\left(\mathrm{CH}_{2}\right)_{2}-$ $\mathrm{CO}-$ ], $3.35 \sim 3.49\left(\mathrm{~m}, 8 \mathrm{H}, \mathrm{Me}_{3} \mathrm{Si}-\mathrm{CH}_{2}-\mathrm{CH}_{2}-, \mathrm{H}-2,5,6\right.$, and $\mathrm{H}-3$ of $\mathrm{C}_{14}-\mathrm{OSEM}$ ), 4.23 (dd, $1 \mathrm{H}, J_{\mathrm{gem}}=12.1 \mathrm{~Hz}$, $J_{5,6}=5.2 \mathrm{~Hz}, \mathrm{H}-6_{\mathrm{b}}$ ), $4.52\left(\mathrm{q}, 1 \mathrm{H}, J_{3,4}=J_{4,5}=J_{4, \mathrm{P}}=8.8 \mathrm{~Hz}\right.$, $\mathrm{H}-4), 4.50 \sim 4.75\left(\mathrm{~m}, 6 \mathrm{H},-\mathrm{OCH}_{2} \mathrm{O}-\right.$ and $\left.\mathrm{CCl}_{3} \mathrm{CH}_{2}-\right), 4.88$ (d, $\left.1 \mathrm{H}, J_{1,2}=8.4 \mathrm{~Hz}, \mathrm{H}-1\right), 5.21\left(\mathrm{~m}, 1 \mathrm{H}, \mathrm{H}-3\right.$ of $\mathrm{C}_{14}-\mathrm{O}$ $\left.\mathrm{C}_{14}\right), 5.50\left(\mathrm{t}, 1 \mathrm{H}, J_{2,3}=J_{3,4}=8.8 \mathrm{~Hz}, \mathrm{H}-3\right)$, and $6.55(\mathrm{~d}, 1 \mathrm{H}$, $J=8.1 \mathrm{~Hz}, \mathrm{NH})$.

Anal. Found: C, 52.88; H, 7.95; N, 0.72. Calcd. for $\mathrm{C}_{67} \mathrm{H}_{124} \mathrm{NO}_{17} \mathrm{Cl}_{6} \mathrm{PSi}_{2}: \mathrm{C}, 53.10 ; \mathrm{H}, 8.25 ; \mathrm{N}, 0.92 \%$.

6-O-/11-[3-/2-(Trimethylsilyl)ethyl 4-O-/bis(2,2,2-trichloroethyl) phosphono 3-2-deoxy-3-O-tetradecanoyl-2$[(3 R)$-3-tetradecanoyloxytetradecanamido $]-\beta-\mathrm{D}-\mathrm{gluco}-$ pyranoside-6-yl-oxycarbonyl /propionamido Jundecanoyl]1-S-acetyl-1-thio-MDP methyl ester (37). To a solution of $31(150 \mathrm{mg}, 0.11 \mathrm{mmol})$ in 1,4-dioxane $(2 \mathrm{ml})$ were added DCC $(50 \mathrm{mg}, 0.25 \mathrm{mmol})$ and $N$-hydroxysuccinimide $(15.5 \mathrm{mg}, 0.13 \mathrm{mmol})$. The mixture was stirred for $30 \mathrm{~min}$ at room temperature, DC urea was filtered off and washed 
Table II.

\begin{tabular}{|c|c|c|c|c|c|c|c|}
\hline \multirow{2}{*}{$\begin{array}{l}\text { Compound } \\
\text { No. }\end{array}$} & \multirow{2}{*}{$\begin{array}{l}\text { Yield } \\
(\%)\end{array}$} & \multirow{2}{*}{$\begin{array}{l}\mathrm{mp} \\
\left({ }^{\circ} \mathrm{C}\right)\end{array}$} & \multirow{2}{*}[\alpha]{$_{\mathrm{D}}$} & \multirow{2}{*}{$\begin{array}{l}\text { Molecular } \\
\text { formula }\end{array}$} & \multicolumn{3}{|c|}{ Found (Calcd.) \% of } \\
\hline & & & & & $\mathrm{C}$ & $\mathrm{H}$ & $\mathrm{N}$ \\
\hline 38 & 46 & 151 & $\begin{array}{l}+6.7^{\circ} \\
\left(c=1.2,1: 1 \mathrm{CH}_{2} \mathrm{Cl}_{2}-\mathrm{CH}_{3} \mathrm{OH}\right)\end{array}$ & $\mathrm{C}_{102} \mathrm{H}_{181} \mathrm{Cl}_{6} \mathrm{~N}_{6} \mathrm{O}_{26} \mathrm{PSSi}$ & $\begin{array}{c}55.18 \\
(55.40)\end{array}$ & $\begin{array}{c}8.49 \\
(8.25)\end{array}$ & $\begin{array}{c}3.67 \\
(3.80)\end{array}$ \\
\hline 39 & 70 & 152.5 & $\begin{array}{l}+7.1^{\circ} \\
\left(c=1.1,1: 1 \mathrm{CH}_{2} \mathrm{Cl}_{2}-\mathrm{CH}_{3} \mathrm{OH}\right)\end{array}$ & $\mathrm{C}_{110} \mathrm{H}_{197} \mathrm{Cl}_{6} \mathrm{~N}_{6} \mathrm{O}_{26} \mathrm{PSSi}$ & $\begin{array}{c}56.71 \\
(56.84)\end{array}$ & $\begin{array}{c}8.81 \\
(8.54)\end{array}$ & $\begin{array}{c}3.34 \\
(3.62)\end{array}$ \\
\hline 46 & 42 & 139 & $\begin{array}{l}+2.9^{\mathrm{c}} \\
\left(\mathrm{c}=1.1, \mathrm{CH}_{2} \mathrm{Cl}_{2}\right)\end{array}$ & $\mathrm{C}_{100} \mathrm{H}_{179} \mathrm{Cl}_{6} \mathrm{~N}_{6} \mathrm{O}_{28} \mathrm{PSSi}_{2}$ & $\begin{array}{c}53.40 \\
(53.49)\end{array}$ & $\begin{array}{c}7.96 \\
(8.04)\end{array}$ & $\begin{array}{c}3.50 \\
(3.74)\end{array}$ \\
\hline 47 & 46 & 166 & $\begin{array}{l}+3.8^{\circ} \\
\left(c=0.9, \mathrm{CH}_{2} \mathrm{Cl}_{2}\right)\end{array}$ & $\mathrm{C}_{108} \mathrm{H}_{195} \mathrm{Cl}_{6} \mathrm{~N}_{6} \mathrm{O}_{28} \mathrm{PSSi}_{2}$ & $\begin{array}{c}54.99 \\
(55.02)\end{array}$ & $\begin{array}{c}8.21 \\
(8.34)\end{array}$ & $\begin{array}{c}3.57 \\
(3.56)\end{array}$ \\
\hline 48 & 36 & 184 & $\begin{array}{l}+1.2^{\circ} \\
\left(c=1.8, \mathrm{CH}_{2} \mathrm{Cl}_{2}\right)\end{array}$ & $\mathrm{C}_{116} \mathrm{H}_{211} \mathrm{Cl}_{6} \mathrm{~N}_{6} \mathrm{O}_{28} \mathrm{PSSi}_{2}$ & $\begin{array}{c}56.49 \\
(56.41)\end{array}$ & $\begin{array}{c}8.40 \\
(8.61)\end{array}$ & $\begin{array}{l}3.56 \\
(3.40)\end{array}$ \\
\hline 55 & 60 & 148 & $\begin{array}{l}+9.9^{\circ} \\
\left(c=1.7,1: 1 \mathrm{CH}_{2} \mathrm{Cl}_{2}-\mathrm{CH}_{3} \mathrm{OH}\right)\end{array}$ & $\mathrm{C}_{102} \mathrm{H}_{181} \mathrm{Cl}_{6} \mathrm{~N}_{6} \mathrm{O}_{26} \mathrm{PSSi}$ & $\begin{array}{c}55.60 \\
(55.40)\end{array}$ & $\begin{array}{c}7.95 \\
(8.25)\end{array}$ & $\begin{array}{c}3.93 \\
(3.80)\end{array}$ \\
\hline 58 & 44 & 130 & $\begin{array}{l}+7.4^{\circ} \\
\left(c=1.6, \mathrm{CH}_{2} \mathrm{Cl}_{2}\right)\end{array}$ & $\mathrm{C}_{98} \mathrm{H}_{177} \mathrm{Cl}_{6} \mathrm{~N}_{6} \mathrm{O}_{27} \mathrm{PSSi}_{2}$ & $\begin{array}{l}53.56 \\
(53.42)\end{array}$ & $\begin{array}{c}8.27 \\
(8.10)\end{array}$ & $\begin{array}{r}3.97 \\
(3.81)\end{array}$ \\
\hline 59 & 61 & $144 \sim 145$ & $\begin{array}{l}+5.2^{\circ} \\
\left(c=1.5, \mathrm{CH}_{2} \mathrm{Cl}_{2}\right)\end{array}$ & $\mathrm{C}_{108} \mathrm{H}_{195} \mathrm{Cl}_{6} \mathrm{~N}_{6} \mathrm{O}_{28} \mathrm{PSSi}_{2}$ & $\begin{array}{c}55.12 \\
(55.02)\end{array}$ & $\begin{array}{c}8.36 \\
(8.34)\end{array}$ & $\begin{array}{c}3.48 \\
(3.56)\end{array}$ \\
\hline 60 & 54 & 146.5 & $\begin{array}{l}+3.3^{\circ} \\
\left(c=1.3, \mathrm{CH}_{2} \mathrm{Cl}_{2}\right)\end{array}$ & $\mathrm{C}_{116} \mathrm{H}_{211} \mathrm{Cl}_{6} \mathrm{~N}_{6} \mathrm{O}_{28} \mathrm{PSSi}_{2}$ & $\begin{array}{c}56.11 \\
(56.41)\end{array}$ & $\begin{array}{c}8.73 \\
(8.61)\end{array}$ & $\begin{array}{c}3.19 \\
(3.40)\end{array}$ \\
\hline 41 & 85 & 101 & $\begin{array}{l}+18.3^{\circ} \\
\left(c=1.1,1: 1 \mathrm{CH}_{2} \mathrm{Cl}_{2}-\mathrm{CH}_{3} \mathrm{OH}\right)\end{array}$ & $\mathrm{C}_{97} \mathrm{H}_{169} \mathrm{Cl}_{6} \mathrm{~N}_{6} \mathrm{O}_{26} \mathrm{PS}$ & $\begin{array}{c}54.95 \\
(55.18) \\
5681\end{array}$ & $\begin{array}{l}8.21 \\
(8.07) \\
8.56\end{array}$ & $\begin{array}{c}3.77 \\
(3.98) \\
3.98\end{array}$ \\
\hline 42 & 70 & 105 & $\begin{array}{l}+16.5^{\circ} \\
\left(c=1.6,1: 1 \mathrm{CH}_{2} \mathrm{Cl}_{2}-\mathrm{CH}_{3} \mathrm{OH}\right)\end{array}$ & $\mathrm{C}_{105} \mathrm{H}_{185} \mathrm{Cl}_{6} \mathrm{~N}_{6} \mathrm{O}_{26} \mathrm{PS}$ & $\begin{array}{l}56.81 \\
(56.72)\end{array}$ & $\begin{array}{c}8.56 \\
(8.39)\end{array}$ & $\begin{array}{c}3.98 \\
(3.78)\end{array}$ \\
\hline 49 & 88 & $95 \sim 96$ & $\begin{array}{l}+8.3^{\circ} \\
\left(c=0.7,1: 1 \mathrm{CH}_{2} \mathrm{Cl}_{2}-\mathrm{CH}_{3} \mathrm{OH}\right)\end{array}$ & $\mathrm{C}_{89} \mathrm{H}_{153} \mathrm{Cl}_{6} \mathrm{~N}_{6} \mathrm{O}_{27} \mathrm{PS}$ & $\begin{array}{c}53.20 \\
(53.05)\end{array}$ & $\begin{array}{c}7.91 \\
(7.65)\end{array}$ & $\begin{array}{c}4.25 \\
(4.17)\end{array}$ \\
\hline 50 & 90 & $70 \sim 72$ & $\begin{array}{l}+10.6^{\circ} \\
\left(c=0.6,1: 1 \mathrm{CH}_{2} \mathrm{Cl}_{2}-\mathrm{CH}_{3} \mathrm{OH}\right)\end{array}$ & $\mathrm{C}_{97} \mathrm{H}_{169} \mathrm{Cl}_{6} \mathrm{~N}_{6} \mathrm{O}_{27} \mathrm{PS}$ & $\begin{array}{c}54.48 \\
(54.77)\end{array}$ & $\begin{array}{c}7.84 \\
(8.01)\end{array}$ & $\begin{array}{c}4.02 \\
(3.95)\end{array}$ \\
\hline 51 & 75 & $73 \sim 75$ & $\begin{array}{l}+6.1^{\circ} \\
\left(c=1.0,1: 1 \mathrm{CH}_{2} \mathrm{Cl}_{2}-\mathrm{CH}_{3} \mathrm{OH}\right)\end{array}$ & $\mathrm{C}_{105} \mathrm{H}_{185} \mathrm{Cl}_{6} \mathrm{~N}_{6} \mathrm{O}_{27} \mathrm{PS}$ & $\begin{array}{c}56.02 \\
(56.32)\end{array}$ & $\begin{array}{c}8.20 \\
(8.33)\end{array}$ & $\begin{array}{c}3.60 \\
(3.75)\end{array}$ \\
\hline 56 & 90 & $85 \sim 88$ & $\begin{array}{l}+19.1^{\circ} \\
\left(c=1.6,1: 1 \mathrm{CH}_{2} \mathrm{Cl}_{2}-\mathrm{CH}_{3} \mathrm{OH}\right)\end{array}$ & $\mathrm{C}_{97} \mathrm{H}_{169} \mathrm{Cl}_{6} \mathrm{~N}_{6} \mathrm{O}_{26} \mathrm{PS}$ & $\begin{array}{c}55.01 \\
(55.18)\end{array}$ & $\begin{array}{c}8.21 \\
(8.07)\end{array}$ & $\begin{array}{c}4.06 \\
(3.98)\end{array}$ \\
\hline 61 & 85 & 103 & $\begin{array}{l}+15.7^{\circ} \\
\left(c=0.5,1: 1 \mathrm{CH}_{2} \mathrm{Cl}_{2}-\mathrm{CH}_{3} \mathrm{OH}\right)\end{array}$ & $\mathrm{C}_{87} \mathrm{H}_{151} \mathrm{Cl}_{6} \mathrm{~N}_{6} \mathrm{O}_{26} \mathrm{PS}$ & $\begin{array}{c}53.11 \\
(52.96)\end{array}$ & $\begin{array}{c}7.63 \\
(7.71)\end{array}$ & $\begin{array}{c}4.02 \\
(4.26)\end{array}$ \\
\hline 62 & 85 & $80 \sim 82$ & $\begin{array}{l}+13.1^{\circ} \\
\left(c=0.8,1: 1 \mathrm{CH}_{2} \mathrm{Cl}_{2}-\mathrm{CH}_{3} \mathrm{OH}\right)\end{array}$ & $\mathrm{C}_{97} \mathrm{H}_{169} \mathrm{Cl}_{6} \mathrm{~N}_{6} \mathrm{O}_{27} \mathrm{PS}$ & $\begin{array}{c}54.93 \\
(54.77)\end{array}$ & $\begin{array}{c}8.30 \\
(8.01)\end{array}$ & $\begin{array}{c}3.78 \\
(3.95)\end{array}$ \\
\hline 63 & 92 & $107 \sim 108$ & $\begin{array}{l}+9.7^{\circ} \\
\left(c=1.5,1: 1 \mathrm{CH}_{2} \mathrm{Cl}_{2}-\mathrm{CH}_{3} \mathrm{OH}\right)\end{array}$ & $\mathrm{C}_{105} \mathrm{H}_{185} \mathrm{Cl}_{6} \mathrm{~N}_{6} \mathrm{O}_{27} \mathrm{PS}$ & $\begin{array}{c}56.36 \\
(56.32)\end{array}$ & $\begin{array}{c}8.39 \\
(8.33)\end{array}$ & $\begin{array}{c}3.50 \\
(3.75)\end{array}$ \\
\hline 44 & 75 & 172 & $\begin{array}{l}+15.6^{\circ} \\
\left(c=0.9,1: 1 \mathrm{CH}_{2} \mathrm{Cl}_{2}-\mathrm{CH}_{3} \mathrm{OH}\right)\end{array}$ & $\mathrm{C}_{93} \mathrm{H}_{167} \mathrm{~N}_{6} \mathrm{O}_{26} \mathrm{PS}$ & $\begin{array}{c}60.63 \\
(60.43)\end{array}$ & $\begin{array}{c}9.34 \\
(9.11)\end{array}$ & $\begin{array}{c}4.81 \\
(4.55)\end{array}$ \\
\hline 45 & 80 & $170 \sim 171$ & $\begin{array}{l}+17.6^{\circ} \\
\left(c=0.9,1: 1 \mathrm{CH}_{2} \mathrm{Cl}_{2}-\mathrm{CH}_{3} \mathrm{OH}\right)\end{array}$ & $\mathrm{C}_{101} \mathrm{H}_{183} \mathrm{~N}_{6} \mathrm{O}_{26} \mathrm{PS}$ & $\begin{array}{c}61.61 \\
(61.87)\end{array}$ & $\begin{array}{c}9.64 \\
(9.41)\end{array}$ & $\begin{array}{c}4.52 \\
(4.29)\end{array}$ \\
\hline 52 & 90 & $161 \sim 163$ & $\begin{array}{l}+10.1^{\circ} \\
\left(c=0.4,1: 1 \mathrm{CH}_{2} \mathrm{Cl}_{2}-\mathrm{CH}_{3} \mathrm{OH}\right)\end{array}$ & $\mathrm{C}_{85} \mathrm{H}_{151} \mathrm{~N}_{6} \mathrm{O}_{27} \mathrm{PS}$ & $\begin{array}{c}58.32 \\
(58.27)\end{array}$ & $\begin{array}{c}8.51 \\
(8.69)\end{array}$ & $\begin{array}{c}4.61 \\
(4.80)\end{array}$ \\
\hline 53 & 89 & $167 \sim 167.5$ & $\begin{array}{l}+13.2^{\circ} \\
\left(c=0.5,1: 1 \mathrm{CH}_{2} \mathrm{Cl}_{2}-\mathrm{CH}_{3} \mathrm{OH}\right)\end{array}$ & $\mathrm{C}_{93} \mathrm{H}_{167} \mathrm{~N}_{6} \mathrm{O}_{27} \mathrm{PS}$ & $\begin{array}{c}60.10 \\
(59.91)\end{array}$ & $\begin{array}{c}9.19 \\
(9.03)\end{array}$ & $\begin{array}{r}4.50 \\
(4.51)\end{array}$ \\
\hline 54 & 80 & $173 \sim 174$ & $\begin{array}{l}+7.3^{\circ} \\
\left(c=0.3,1: 1 \mathrm{CH}_{2} \mathrm{Cl}_{2}-\mathrm{CH}_{3} \mathrm{OH}\right)\end{array}$ & $\mathrm{C}_{101} \mathrm{H}_{183} \mathrm{~N}_{6} \mathrm{O}_{27} \mathrm{PS}$ & $\begin{array}{c}61.53 \\
(61.37)\end{array}$ & $\begin{array}{c}9.50 \\
(9.33)\end{array}$ & $\begin{array}{c}4.24 \\
(4.25)\end{array}$ \\
\hline 57 & 82 & $174 \sim 175$ & $\begin{array}{l}+18.2^{\circ} \\
\left(c=1.2,1: 1 \mathrm{CH}_{2} \mathrm{Cl}_{2}-\mathrm{CH}_{3} \mathrm{OH}\right)\end{array}$ & $\mathrm{C}_{93} \mathrm{H}_{167} \mathrm{~N}_{6} \mathrm{O}_{26} \mathrm{PS}$ & $\begin{array}{c}60.19 \\
(60.43)\end{array}$ & $\begin{array}{l}9.30 \\
(9.11)\end{array}$ & $\begin{array}{c}4.26 \\
(4.55)\end{array}$ \\
\hline 64 & 87 & $177 \sim 178$ & $\begin{array}{l}+17.3^{\circ} \\
\left(c=0.5,1: 1 \mathrm{CH}_{2} \mathrm{Cl}_{2}-\mathrm{CH}_{3} \mathrm{OH}\right)\end{array}$ & $\mathrm{C}_{83} \mathrm{H}_{149} \mathrm{~N}_{6} \mathrm{O}_{26} \mathrm{PS}$ & $\begin{array}{c}58.51 \\
(58.30)\end{array}$ & $\begin{array}{c}8.60 \\
(8.78)\end{array}$ & $\begin{array}{c}4.99 \\
(4.91)\end{array}$ \\
\hline 65 & 90 & $137 \sim 138$ & $\begin{array}{l}+14.3^{\circ} \\
\left(c=0.5,1: 1 \mathrm{CH}_{2} \mathrm{Cl}_{2}-\mathrm{CH}_{3} \mathrm{OH}\right)\end{array}$ & $\mathrm{C}_{93} \mathrm{H}_{167} \mathrm{~N}_{6} \mathrm{O}_{27} \mathrm{PS}$ & $\begin{array}{c}59.68 \\
(59.91)\end{array}$ & $\begin{array}{c}8.73 \\
(9.03)\end{array}$ & $\begin{array}{c}4.76 \\
(4.51)\end{array}$ \\
\hline 66 & 88 & $168 \sim 169$ & $\begin{array}{l}+10.1^{\circ} \\
\left(c=1.0,1: 1 \mathrm{CH}_{2} \mathrm{Cl}_{2}-\mathrm{CH}_{3} \mathrm{OH}\right)\end{array}$ & $\mathrm{C}_{101} \mathrm{H}_{183} \mathrm{~N}_{6} \mathrm{O}_{27} \mathrm{PS}$ & $\begin{array}{c}61.66 \\
(61.37)\end{array}$ & $\begin{array}{c}9.14 \\
(9.33)\end{array}$ & $\begin{array}{c}4.44 \\
(4.25)\end{array}$ \\
\hline
\end{tabular}


with dichloromethane. The filtrate and washings were combined and concentrated to give the activated compound, which was used for the next coupling reaction without further purification.

The compound just obtained and triethylamine ( $1 \mathrm{drop}$ ) were added to a solution of $9(60 \mathrm{mg}, 0.07 \mathrm{mmol})$ in DMF $(1 \mathrm{ml})$ at room temperature. The mixture was stirred for $\mathrm{lhr}$, and then concentrated to a syrup, which was chromatographed on a column of silica gel with dichloromethane-methanol $(20: 1)$ to afford the coupling compound $37\left(82.9 \mathrm{mg}, 57^{\circ}\right)$, mp $145 \sim 146^{\circ} \mathrm{C},[\alpha]_{D}+5.9^{\circ}$ ( $c=1.0,1: 1$ dichloromethane-methanol); IR $v_{\max }$ (film) $\mathrm{cm}^{-1}: 3280(\mathrm{OH}, \mathrm{NH}), 2940$ and $2850(\mathrm{C}-\mathrm{H}), 1740$ (ester), 1690 (AcS), 1570 and 1550 (amide), $920\left(\mathrm{P}-\mathrm{O}-\mathrm{CH}_{2}\right), 840$ $(\mathrm{Si}-\mathrm{C})$, and 800 and $720(\mathrm{C}-\mathrm{Cl}) ; \mathrm{NMR}\left(\mathrm{CDCl}_{3}+\mathrm{CD}_{3} \mathrm{OD}\right)$ $\delta: 0.0\left(\mathrm{~s}, 9 \mathrm{H}, \mathrm{Me}_{3} \mathrm{Si}\right), 0.88\left(\mathrm{~m}, 11 \mathrm{H}, \mathrm{Me}_{3} \mathrm{Si}-\mathrm{CH}_{2}-\right.$ and acylMe), $1.41 \sim 1.25\left(\mathrm{~m}, 86 \mathrm{H},-\mathrm{CH}_{2}-\right.$, lac-Me, and ala-Me), $1.92(\mathrm{~s}, 3 \mathrm{H}, \mathrm{AcN}), 2.35(\mathrm{~s}, 3 \mathrm{H}, \mathrm{AcS}), 2.71(\mathrm{~m}, 2 \mathrm{H}$, $-\mathrm{OCOCH}_{2}-$ ), $3.68(\mathrm{~s}, 3 \mathrm{H}, \mathrm{MeO}), 4.62\left(\mathrm{~m}, 4 \mathrm{H}, \mathrm{CCl}_{3} \mathrm{CH}_{2}-\right.$ ), $4.71\left(\mathrm{~d}, 1 \mathrm{H}, J_{1,2}=8.4 \mathrm{~Hz}, \mathrm{H}-1\right.$ of GLA-27 unit), 5.03 (m, $1 \mathrm{H}, \mathrm{H}-3$ of $\left.\mathrm{C}_{14}-\mathrm{O}-\mathrm{C}_{14}\right), 5.11\left(\mathrm{~d}, 1 \mathrm{H}, J_{1,2}=10.6 \mathrm{~Hz}, \mathrm{H}-1\right.$ of MDP unit), and $5.38\left(\mathrm{t}, 1 \mathrm{H}, J_{2.3}=J_{3.4}=9.5 \mathrm{~Hz}, \mathrm{H}-3\right.$ of GLA-27 unit).

Anal. Found: C, 53.49; H, 8.11; N, 3.81. Calcd. for $\mathrm{C}_{94} \mathrm{H}_{165} \mathrm{~N}_{6} \mathrm{O}_{26} \mathrm{Cl}_{6}$ PSSi: C, 53.78; H, 7.92; N, $4.00 \%$.

Other coupling products $(38,39,46 \sim 48,55$ and $\mathbf{5 8} \sim 60)$. The title compounds were synthesized by coupling 10,11 and 18 with 31 , and $9 \sim 11$ and $17 \sim 19$ with 36, respectively, as described for 37 . The IR and NMR spectra were consistent with the structures assigned, their yields and physical data being recorded in Table II.

6-O-[1]-[3-[4-O-[Bis(2,2,2-trichloroethyl)phosphono]2-deoxy-3-O-tetradecanoyl-2-[(3R)-3-tetradecanoyloxytetradecanamido ]-D-glucopyranose-6-yl-oxycarbonyl]propionamido JundecanoylJ-1-S-acetyl-1-thio-MDP methyl ester (40). Compound $37(90 \mathrm{mg}, 0.04 \mathrm{mmol}$ ) was dissolved in dichloromethane $(1 \mathrm{ml})$, boron trifluoride etherate $(0.1$ $\mathrm{ml}$ ) was added at $0^{\circ} \mathrm{C}$, and the mixture was then stirred overnight at room temperature. Methanol and water were added, and the reaction mixture was neutralized with Amberlite IR-410 $\left(\mathrm{OH}^{-}\right)$resin. The resin was filtered off and washed with dichloromethane. The filtrate and washings were combined and concentrated to give the title compound $\mathbf{4 0}$ (84 $\mathrm{mg}$, quant.) which was crystallized from water, mp $97 \sim 98.5^{\circ} \mathrm{C},[\alpha]_{\mathrm{D}}+12.5(c=2.1,1: 1$ dichloromethane-methanol); IR $v_{\max }\left(\right.$ film) $\mathrm{cm}^{-1}: 3400(\mathrm{OH}, \mathrm{NH})$, 2940 and $2850(\mathrm{C}-\mathrm{H}), 1720$ (ester), $1680(\mathrm{AcS}), 1660$ and 1530 (amide), $900\left(\mathrm{P}-\mathrm{O}-\mathrm{CH}_{2}\right)$, and 800 and $720(\mathrm{C}-\mathrm{Cl})$; NMR $\left(\mathrm{CDCl}_{3}+\mathrm{CD}_{3} \mathrm{OD}\right) \delta: 0.9(\mathrm{t}, 9 \mathrm{H}$, acyl-Me), $1.29 \sim$ $1.62\left(\mathrm{~m}, 86 \mathrm{H},-\mathrm{CH}_{2}-\right.$, lac-Me, and ala-Me), $1.92(\mathrm{~s}, 3 \mathrm{H}$, $\mathrm{AcN}), 2.36(\mathrm{~s}, 3 \mathrm{H}, \mathrm{AcS}), 2.59\left(\mathrm{t}, 2 \mathrm{H},-\mathrm{COCH}_{2}-\right), 3.08$ (t, $2 \mathrm{H},-\mathrm{CH}_{2} \mathrm{NHCO}-$ ), $3.69(\mathrm{~s}, 3 \mathrm{H}, \mathrm{MeO}), 5.03 \sim 5.15(\mathrm{~m}, 3 \mathrm{H}$, H- 1 of GLA-27 unit, $\mathrm{H}-3$ of $\mathrm{C}_{14}-\mathrm{O}-\mathrm{C}_{14}$, and $\mathrm{H}-1$ of MDP unit), and $5.44\left(\mathrm{t}, 1 \mathrm{H}, J_{2,3}=J_{3.4}=9.2 \mathrm{~Hz}, \mathrm{H}-3\right.$ of GLA-27 unit).
Anal. Found: C, 53.20; H, 7.90; N, 4.22. Calcd. for $\mathrm{C}_{89} \mathrm{H}_{153} \mathrm{~N}_{6} \mathrm{O}_{26} \mathrm{Cl}_{6}$ PS: C, 53.48; $\mathrm{H}, 7.71 ; \mathrm{N}, 4.20 \%$.

Other desilylated derivatives $(41,42,49 \sim 51,56$ and $61 \sim$ 63). Compounds $41,42,49 \sim 51,56$ and $61 \sim 63$ were obtained as crystals, by desilylating of $38,39,46 \sim 48,55$ and $58 \sim 60$ according to the method described for 40 . The IR and NMR data were consistent with the structures assigned, and their yields and physical data are recorded in Table II.

6-O-/11-[3-[2-Deoxy-4-O-phosphono-3-O-tetradecanoyl-2- $[(3 R)-3$-tetradecanoyloxytetradecanamido $]-\mathrm{D}-$ glucopyranose-6-yl-oxycarbonyl Jpropionamido Jundecanoyl]-IS-acetyl-1-thio-MDP methyl ester (43). To a solution of $\mathbf{4 0}$ $(80 \mathrm{mg}, 0.04 \mathrm{mmol})$ in acetic acid $(1.5 \mathrm{ml})$ was added zinc dust $(900 \mathrm{mg})$ at $45^{\circ} \mathrm{C}$. After $20 \mathrm{~min}$, the solid was filtered off, and washed with acetic acid. The filtrate and washings were combined and concentrated. The residual syrup was dissolved in methanol, and the solution was deionized with Amberlite IR-120 $\left(\mathrm{H}^{+}\right)$resin. The resin was filtered off, and washed with methanol and dichloromethane. The filtrate and washings were combined and concentrated to yield $43(69 \mathrm{mg}, 92 \%)$, which was crystallized from water. 43 gave a positive test for the phosphate group, using the phosphomolybdate spray reagent, ${ }^{16)} \mathrm{mp} 171^{\circ} \mathrm{C},[\alpha]_{\mathrm{D}}$ $+13.1^{\circ}(c=1.4,1: 1$ dichloromethane-methanol $)$; IR $y_{\max }$ $(\mathrm{KBr}) \mathrm{cm}^{-1}: 3350(\mathrm{OH}, \mathrm{NH}), 2940$ and $2860(\mathrm{C}-\mathrm{H}), 1740$ (ester), 1680 ( $S$-acyl), and 1660 and 1550 (amide).

Anal. Found: C, $58.66 ; \mathrm{H}, 8.88 ; \mathrm{N}, 4.96$. Calcd. for $\mathrm{C}_{85} \mathrm{H}_{151} \mathrm{~N}_{6} \mathrm{O}_{26}$ PS: C, $58.80 ; \mathrm{H}, 8.77 ; \mathrm{N}, 4.84 \%$.

Other deprotected conjugates $(\mathbf{4 4}, \mathbf{4 5}, 52 \sim 54,57$ and $64 \sim 66)$. These compounds were respectively prepared by de-trichloroethylation of $41,42,49 \sim 51,56$ and $61 \sim 63$, as described for $\mathbf{4 3}$, and showed similar IR data. Their yields and physical data are shown in Table II.

\section{References}

1) a) A. Hasegawa, E. Seki, Y. Fujishima, K. Kigawa, M. Kiso, H. Ishida and I. Azuma, J. Carbohydr. Chem., 5, 371 (1986); b) Y. Fujishima, K. Kigawa, Y. Ogawa, M. Kiso, A. Hasegawa, H. Ishida and I. Azuma, Carbohydr. Res., 167, 317 (1987).

2) E. Lederer, J. Med. Chem., 23, 819 (1980).

3) C. Galanos, O. Lüderitz, E. T. Rietschel and O. Westphal, in T. W. Goodwin (ed.), Biochemistry of Lipids II, Int. Rev. Biochem., 14, 239 (1977).

4) A. Hasegawa, Y. Hioki, E. Seki, M. Kiso and I. Azuma, Agric. Biol. Chem., 50, 1873 (1986).

5) a) M. Kiso, H. Ishida and A. Hasegawa, Agric. Biol. Chem., 48, 251 (1984); b) M. Kiso, S. Tanaka, M. Tanahashi, Y. Fujishima, Y. Ogawa and A. Hasegawa, Carbohydr. Res., 148, 221 (1986).

6) S. Ikeda, Y. Kumazawa, K. Sai, C. Nishimura, M. 
Nakatsuka, J. Y. Homma, A. Yamamoto, M. Kiso and A. Hasegawa, Int. J. Immunopharmac., 10, 339 (1988).

7) a) A. Hasegawa, Y. Hioki, E. Yamamoto, M. Kiso and I. Azuma, J. Carbohydr. Chem., 5, 359 (1986); b) A. Hasegawa, Y. Hioki, M. Kiso, H. Okumura and I. Azuma, Carbohydr. Res., 123, 183 (1983).

8) S. Nagao, H. Takada, K. Yagawa, H. Kutsukake, T. Shiba, S. Kusumoto, S. Kawata, A. Hasegawa, M. Kiso, I. Azuma, A. Tanaka and S. Kotani, Infec. Immun., 55, 1279 (1987).

9) a) M. Kiso, S. Tanaka, M. Fujita, Y. Fujishima, Y. Ogawa, H. Ishida and A. Hasegawa, Carbohyd. Res., 162, 127 (1987); b) M. Kiso, S. Tanaka, M. Fujita, Y. Fujishima, Y. Ogawa and A. Hasegawa, ibid., 162, 247 (1987); c) M. Kiso, Y. Ogawa, Y. Fujishima, M. Fujita, S. Tanaka and A. Hasegawa, J. Carbohydr. Chem., 6, 625 (1987).

10) a) Y. Kumazawa, M. Nakatsuka, H. Takimoto, T.
Furuya, T. Nagumo, J. Y. Homma, A. Yamamoto, K. Inada, M. Yoshida, M. Kiso and A. Hasegawa, Infect. Immun., 56, 149 (1988); b) S. Ikeda, C. Nishijima, M. Nakatsuka, J. Y. Homma, M. Kiso and A. Hasegawa, Antiviral Res., 9, 37 (1988).

11) B. H. Lipshutz, J. J. Pegram and M. C. Morey, Tetrahedron Lett., 22, 4603 (1981).

12) B. H. Lipshutz and J. J. Pegram, Tetrahedron Lett., 21, 3343 (1980).

13) K. Jansson, T. Frejd, J. Kinlberg and G. Magnusson, Tetrahedron Lett., 27, 753 (1986).

14) M. Kiso and L. Anderson, Carbohydr. Res., 136, 309 (1985).

15) I. Azuma, H. Okumura, I. Saiki, Y. Tanio, M. Kiso, A. Hasegawa and Y. Yamamura, Infect. Immun., 32, 1305 (1981).

16) J. C. Dittmer and R. L. Lester, J. Lipid Res., 5, 126 (1964). 